\title{
On Vino Veritas? Clarifying the Use of Geographic References on American Wine Labels
}

\author{
Michael Maher
}

Geographical indications of origin are important tools for consumer protection and product differentiation in the wine industry. The federal Bureau of Alcohol, Tobacco, and Firearms ("ATF") regulates their use on American wine labels. However, geographic terms also may appear on American wine labels in several other contexts, including as brand names, winery addresses, wine types, or even as grape variety names. These geographic terms often conflict with a wine's geographical indication of agricultural origin. This Comment examines the core purposes of ATF's winelabeling regulatory scheme and compares these purposes to the similar purposes of trademark law. Applying consumer confusion and dilution analyses of trademark law to wine label content, this Comment argues that significant inconsistencies in ATF's regulation of geographic terms undermine its ability to serve its core regulatory purposes. These "nonconformities" in ATF's overall zoning scheme for the use of product descriptors on wine labels have produced a great deal of industry debate in recent years, as well as much political and legal maneuvering, yet the wine industry appears incapable of reaching consensus on a resolution to these issues. This Comment sets forth a comprehensive reform proposal that borrows the most promising aspects of existing reform proposals while incorporating a solution often applied in the zoning context: a phase-out of nonconforming uses over a reasonable amortization period. This comprehensive proposal would provide a meaningful and necessary resolution

Copyright $(2001$ Califomia Law Review, Inc. Califomia Law Review, Inc. (CLR) is a California nonprofit corporation. CLR and the authors are solely responsible for the content of their publications.

i J.D. Candidate, School of Law, University of California, Berkeley (Boalt Hall), 2002; A.B., Duke University, 1997. I would like to thank Professor Joel Fleishman of Duke University, Zelma Long, and Jean-Michel Cazes, all of whom entertained and fueled my interest in wine, while teaching me a great deal about the product and the business. I also owe much thanks to Robert Tinlot, Stephen Stern, and Richard Mendelson for their scholarship and advocacy in this field. Finally, I wish to thank the members of the California Law Review, especially Mara Krongard, Lauren Sudar, and Jason Snyder, for their thoughtful and careful editing of this manuscript. 
to the current conflict, while respecting both constitutional and commercial prerogatives.

\section{INTRODUCTION}

Geographic references on wine labels in the United States often are confusing and misleading. A simple illustration: A recent trip to the local grocery store in California found on the shelves a 1997 Napa Ridge Central Coast Cabernet Sauvignon and a 1997 Rutherford Vineyards Stanislaus County Cabernet Sauvignon. These wines, however, come neither from Napa nor from Rutherford. These examples illustrate an increasingly controversial clash between government-required indicators of agricultural origin and geographically inaccurate brand names. This conflict recently has been the subject of legislation in California. Under a California law that was intended to go into effect on January 1, 2001, any similarly labeled wines produced after this date would have been illegal.' ${ }^{1}$ A California state appellate court, however, enjoined the law pending that court's resolution of challenges to the law's constitutionality. ${ }^{2}$ This Comment reviews the circumstances and the regulatory franework that led California to pass this legislation. It supports the action taken by California, but argnes that this conflict needs to be resolved through broad regulatory reforn at the federal level.

The federal wine-labeling regulatory scheme promulgated by the U.S. Bureau of Alcohol, Tobacco and Firearnis ("ATF") in many ways can be analogized to a comprehensive municipal zoning scheme. ATF's winelabeling regime limits the use of certain terms on wine labels to specific products in much the same way as zoning plans limit certain types of property uses to specific areas. The "properties" regulated by ATF include ownerless descriptive terms (for example, geographic place names, grape variety names, and "estate bottled") and geographic brand names, often registered as trademarks by the wine producers who use them. Like most zoning schemes, ATF's wine-labeling scheme encompasses a number of "nonconforming uses." Unlike most zoming schemes, however, ATF's current scheme has neither provisions for limiting the expansion of nonconforming uses, nor provisions for the eventual termination of such uses. Nonconforming uses are particularly troublesome in the context of geographic terms, and ATF's allowance of unconstrained and perpetual use

1. CAL. Bus. \& Prof. Code $\$ 25241$ (West Supp. 2001); see discussion infra Part 1I.C.3.

2. See Bronco Wine Co. v. Espinoza, No. C037254 (Cal. Ct. App. filed Dec. 22, 2001); see infra note 145 and accompanying text.

3. The concept of nonconforming uses makes sense only in the context of zoning. The term nonconforming use is a use (of land or premises) that existed lawfully prior to the enactment of a zoning ordinance and that continues after enactment of a zoning ordinance, but is not in conformity with the restrictions placed on the zone in which it is situated. See infra notes 151-152 and accompanying text. 
of nonconformities undermines the main purpose of ATF's labeling scheine.

Part I of this Comment describes the historical importance of geographical indications and trademarks to the wine business. Part II examines the core purposes of ATF's wine-labeling authority under the Federal Alcohol Administration Act and the similar core purposes of trademark law under the Lanham Trade-Mark Act. It then traces the evolution of relevant ATF labeling regulations and their interactions with trademark law as shaped by legislation, rulemaking procedures, case law, and international obligations. Finally, Part II describes how the issue of geographical indications on wine labels was recently thrust into the political and judicial spotlight in California after the industry failed to reach a consensus on whether, and how, to amend the relevant ATF regulations.

Part III describes the nonconforming uses of geographic terms on American wine labels. It describes how inconsistencies in the current regulatory regime, which allow for potentially perpetual and unlimited expansion of nonconforming uses, seriously undermine the core purposes of both ATF's wine-labeling regulations and trademark law. Such uses both confuse consumers and dilute the value of regional names. This Comment argues that the purposes of the labeling regulatory regime would best be served by borrowing a solution commonly applied to nonconforming uses im municipal zoning: a phaseout of such uses over a reasonable amortization period. This solution, if impleinented at the federal level, would withstand constitutional challenges and provide a comprehensive, meaningful, commercially feasible, and constitutionally sound resolution of the current controversy surrounding the use of geographic references on American wine labels.

I

BACKground: GeograpHIC RefERENCES on Wine LABELS

\section{A. The Importance of Geographic References in the Wine Trade}

Unlike most consunier products, wine has been made in more or less its current form not just for decades or centuries, but for millennia. ${ }^{4}$ Even in the early days of wine production, geographical indications were applied to containers as a means of classification. Ancient Egyptians regularly stamped wine jars or painted them with vintage and provenance. ${ }^{5}$ The Roman amphora, a pottery container of approximately twenty-six liters, always carried or attached an inscription indicating its place of origin. ${ }^{6}$ As

4. Hugh Johnson, The StORY OF WiNe 15 (photo. reprint 1996) (1989) ("Little has changed in Imeretian custom since the time of Homer, and in the way wine is made, almost nothing since prehistoric times.").

5. Id. at 32 .

6. Jean-François Gautier, Le Vin et Ses Fraudes 43 (1995). 
the wine trade grew, so did the complexity of the inscriptions appearing on amphorae. $^{7}$

Notoriety, it appears, has long been a catalyst for fraud. ${ }^{8}$ The concept of geographical indications relies on the assumption, almost universally accepted today in the wine industry, that different environments produce different wine grapes and, thus, wines of different characteristics. ${ }^{9}$ As a region or a producer gains repute as a source of a distinct and desirable product, imitations appear and the battle against fraud begins. Just as today we strive to create more complex, counterfeit-proof product identifiers for such valuable consumer products as computer software and compact discs, so did the Romans 2,000 years ago with their valuable wine containers. Codes, logos, numbers, drawings, and letters all served to certify the origin of Roman wines and to make fraud more difficult. ${ }^{10}$

At the beginning of the eighteenth century, law began to protect consumers from fraudulent geographical indications. In 1716, for example, Medici Grand Duke Cosimo 1 II of Florence issued an edict establishing geographic delimitations on Tuscan wine grape-growing regions, most notably Chianti, Carmignano, and Pomino. ${ }^{11}$ This decree fixed boundaries for these regions and forbade merchants in other regions from using these geographic names on wines not grown in the delimited areas. ${ }^{12}$ Forty years later, in 1756, a legal vineyard delimitation was created in the Duoro Valley of Portugal, establishing a specific area in the upper Duoro where growers would receive higher prices for their wines than those produced from grapes grown elsewhere. ${ }^{13}$

7. See id. at 44 .

8. Fraudulently labeled wines were commonplace even in ancient Rome. See GaUTIER, supra note 6, at 44 (citing Robert Tinlot, L'etiquetage, Depuis Quand? LA Vigne et le Vin (1988)).

9. If this were not the case, it would be curious indeed that every major wine-producing nation has established a system delimiting geographic regions and regulating their use on wine labels. See infra note 17. While American wine regions, and those of many "New World" wine-producing nations such as Australia, are defined with no regard to or examination of wine quality, see infra note 91 and accompanying text for discussion of the American system, many wine-labeling regimes throughout the world require wines originating from within a designated appellation to follow strict growing and production techniques, and to meet quality standards before receiving the necessary label approval. See, e.g., Robert Tinlot \& Yann Juban, Différents Systèmes d'Indications Géographiques et Appellations d'Origine, Leurs Relations avec L'Harmonisation Internationale (unpublished manuscript, on file with author) (describing the various systems of protecting regional names for wines). The primary exception is the German system of classification. While the German system provides for the use of vineyard and regional names, it does not focus primarily on geography. Instead, its wine-labeling system is centered on categories based on the sugar levels of grapes at harvest. See id.; see also OxForo Companion To WINE 44I (Jancis Robinson ed., 1994).

10. See Gautier, supra note 6, at 44 .

11. LAROUSSE ENCYClOPEDIA OF WINE 127, 376 (1994).

12. Id.

13. OXFORD COMPANION to WINE, supra note 9, at 321. 
By the early twentieth century, the wine industry in Europe faced enormous fraud and adulteration problems. ${ }^{14}$ In response, national governments formally delimited grape-growing areas used in wine production, beginning with a French law in 1905 designed to combat fraudulent wine labeling ${ }^{15}$ that eventually, through subsequent laws in 1919, 1927, and 1935, created the well-known French appellation of origin systein for wines, spirits, cheeses, and various other agricultural products. ${ }^{16}$ Today, every major wine-producing nation has a regulatory regime for wine labeling that incorporates geographic delimitations of grape-growing regions. ${ }^{17}$ The particular importance of geographical indications to the wine trade is underscored by the express protection of such indications in four international agreements. ${ }^{18}$

The earliest efforts to protect geographical indications shared the same basic motivations as today's efforts. ${ }^{19}$ Two fundainental goals continue to drive the effort to protect a geographical indication of origin: the creation of a distinctive product identifier and the assurance to the consumer of the authenticity of products bearing that identifier.$^{20}$ Economic and consumer protection concerns underlie these goals. For producers, geographical indications serve as marketing tools. ${ }^{21}$ Limiting production

14. See id. at 321,322 . See also GAUTIER, supra note 6, at 76-78.

15. See LAROuSSE, supra note 11, at 127; GAUTIER, supra note 6, at 78; OXFord Companion to WINE, supra note 9, at 321-22.

16. See LARousse, supra note 11, at 127; Gautier, supra note 6, at 78; OxFord Companion to WINE, supra note 9, at 321-22. The French appellation d'origine contrôlée ("AOC") system regulates not only origin of grapes, but also production location, growing methods, and production methods for a variety of agricultural products. LAROusse, supra note 11, at 132-33.

17. The world's largest wine-producing countries are ltaly (roughly 1.43 billion gallons produced in 1998), France (1.39 billion), Spain ( 800 million), United States (540 million), Argentina (335 million), Germany (286 million), South Africa (215 million), Australia (196 million), and Chile (144 million), which together account for approximately $80 \%$ of the total world wine production. See Key Facts: World Wine Production by Country, at http://www.wineinstitute.org/communications/statistics/ keyfacts_worldwineproduction.htm (last visited Oct. 24, 2001). Each of these countries has such a system. See LAROUSSE, supra note 11, at 564.

18. See Paris Convention for the Protection of Industrial Property, Mar. 20, 1883, arts. 1, 10, 25 Stat. 1372, 82 U.N.T.S. 305; Madrid Agreement for the Repression of False or Deceptive Indications of Source on Goods, Apr. 14, 1891, 175 C.T.S. 53, 18 Martens (2d) 839; Lisbon Agreement for thc Protection of Appellations of Origin and Their International Registration, Oct. 31, 1958, 1968 R.T.A.F. 33; General Agreement on Tariffs and Trade-Multilateral Trade Negotiations (The Uruguay Round): Agreement on Trade-Related Aspects Of Intellectual Property Rights, Including Trade in Counterfeit Goods, Dec. 15, 1993, arts. 22-24, 33 I.L.M. 81 [hereinafter TRIPs Agreement].

19. See OXFORD COMPANION to WINE, supra note 9, at 321.

20. See GAuTIER, supra note 6, at 47-48.

21. See, e.g., Kirby Moulton \& Tony Spawton, The Challenge of Maintaining Competitiveness in a Regulated Economy, Symposium Presentation, The Fourth International Symposium on Cool Climate Viticulture and Enology, American Society of Enology and Viticulture, Rochester, New York, 8-9 (July 20,1996) (unpublished nuanuscript, on file with author) (describing regional designation as one of the primary bases for wine product differentiation); Janet Fletcher, The Grape Divide-Location, S.F. CHroN., Nov. 10, 1999, at A1 ("[V]intners are increasingly focusing on place to remind consuniers that great wines don't come from just anywhere."); Eleanor Heald \& Ray Heald, Growing Distinctive 
areas and developing regional notoriety provide monopolistic protection and value-added. ${ }^{22}$ For consumers, guarantees of origin provide assurances against fraud and information to reduce confusion. ${ }^{23}$

\section{B. The Coexistence of Wine Appellations and Trademarks}

The importance of geographical indications relative to trademarks in the wine trade varies between producing nations, and is generally a function of the age of a nation's economy and wine industry. ${ }^{24}$ This relative importance is reflected not just in producer labeling practices but also in regulatory schemes and institutions. ${ }^{25}$

The relative importance of geographical indications versus trademarks has evolved differently in the United States than in Europe. The creation of additional means of product differentiation, such as logos, trademarks, and brand names, only became necessary in Europe as economies became increasingly market-based; with increasing competition among local producers, new tools were needed to distinguish products from the same region. ${ }^{26}$ Even now, in many traditional European wine-producing regions, trademarks remain of secondary importance after geographic place names. ${ }^{27}$ In the relatively young U.S. marketplace, where market competition has existed from the outset, brand names historically have been of greater prominence on wine labels as distinguishing wine identifiers. ${ }^{28}$ An American regulatory scheme for identifying wine regions has developed only recently, ${ }^{29}$ as producers seek to capitalize on and protect the goodwill they have developed in association with their wine regions. ${ }^{30}$ Accordingly, the

Cabernet Sauvignon, Practical Winery \& VineYARD, Mar.-Apr. 1999, at 48 (describing the efforts of one small viticultural area to distinguish the grapes and wines originating from that area).

22. Wine writer Jancis Robinson explains:

The central feature of geographical delimitation as it applies to wine is not just that it usually leads to an improvement in wine quality, thus enabling the wines to be sold at a higher price, but also that it is a legislative procedure whereby a privileged monopolistic position is created for producers within a demarcated area. Whether a given vineyard falls within or outside the legal boundary of a delimited wine region can have important commercial consequences, which is why the much more recent demarcation of America's [wine regions] can be such a contentious process.

OXFord COMPANION TO WINE, supra note 9, at 322.

23. See infra Part Il.A.

24. Lee Bendekgey \& Caroline H. Mead, Intemational Protection of Appellations of Origin and Other Geographic Indications, 82 TRADEMARK REP. 765, 765-66 (1992).

25. See Moulton \& Spawton, supra note 21, at 6.

26. See Bendekgey \& Mead, supra note 24 , at 765 .

27. See LAROUsse, supra note 11 , at 50-52.

28. See id. at 52 .

29. See infra Part I.B.

30. See Moulton \& Spawton, supra note 21 , at 9 ("Regional designation is clearly an important basis for product differentiation and it results from strong industry efforts to influence public policy to protect regional producers.”). See also Beth A. Benjamin \& Joel M. Podolny, Status, Quality, and Social Order in the California Wine Industry, 44 ADMIN. ScI. Q. 563, 569 (1999) ("It is widely recognized that the motive foree behind most viticultural affiliations lies in the perceptual impact that 
use of geographical indications is less entrenched in the United States than in many other wine-producing countries. However, prior to the creation of the American regulatory scheme governing the use of geographic terms, brand names and trademarks frequently incorporated geographic terms. ${ }^{31}$

The use of geographical indications on wine labels has divided the domestic wine industry lobby in recent years. ${ }^{32}$ This division is due in part to the tremendously concentrated, yet highly fragmented, structure of the American wine industry, ${ }^{33}$ a handful of producers account for over twothirds of total production. ${ }^{34}$ These large, economically powerful producers sell wines in all segments of the marketplace. ${ }^{35}$ Among their products are American-grown wines labeled under European geographical indications such as Chablis, Champagne, Port, Sherry, and Burgundy, and brand names such as Napa Ridge and Monterey Cellars. Over 2,000 other wineries $^{36}$ compete for the remaining chunk of the market, which resides mainly in the higher price categories. These producers often market their wines with both a trademark and a domestic appellation. ${ }^{37}$ This market structure and history has produced an industry of diverse players with diverse interests, a fact which becomes apparent when ATF solicits comments during its rulemaking procedures. ${ }^{38}$ Not surprisingly, different industry opinions have led to interually inconsistent federal regulations and to an impasse in resolving current oversights and problem areas in the regulation of geographical indications on American wine labels.

\section{II \\ THE AmErican Regulatory ENVIRONMENT \\ A. The Core Purposes of ATF's Wine-labeling Policies and the Lanham Act}

The Federal Alcohol Administration Act ("FAA Act") of 1935, codified in 27 U.S.C. $\$ \S 201-219$ a, establishes the regnlatory scheme that

such affiliations have on consumers' assessments of quality and the economic impact that such perceptions have on the winery's ability to price its wine.").

31. See infra Part II.

32. See infra Part II.C.

33. See Jeremy D. Taylor, Understanding Industry Risk: Part 3, J. LeNDING \& CREDIT RISK MGMr., Oct. 1996, at 14, 17.

34. E \& J Gallo Winery, the world's largest winery, accounts for over one-quarter of American wine production. The top ten producers account for over $70 \%$ of the U.S. wine market. See ADAMS WINE HANDBOOK 101 (1999).

35. See Taylor, supra note 33 , at 16 .

36. See Kim Marcus, U.S. Winery Total Grows at Fast Pace, Wine Spectator, Sept. 15, 1999, at 21 .

37. See supra note 21.

38. Cf. Labeling and Advertising of Wine: Appellation of Origin, Grape-Type Designations, Etc., 43 Fed. Reg. 37,67I (Aug. 23, 1978) (hereinafter Labeling and Advertising Rule) (ATF describing the various comments received in response to its earlier notices of proposed rulemaking). 
governs the bottling, packaging, marketing, and labeling of wine. The legislative intent of the FAA Act was to prohibit practices in the alcoholic beverages industry "that Congress had judged to be unfair and deceptive, resulting in harm to both competitors and consumers." ${ }^{39}$ The Administrator of the Federal Alcohol Control Administration (ATF's predecessor agency) stated the consumer protection elements of the FAA Act at the time of the Act's passage:

Those regulations were intended to ensure that the purchaser should get what he thought he was getting, that representations both in labels and in advertising should be honest and straight forward and truthful. They should not be confined... to prohibitions of falsity, but they should also provide for the information of the consumer, that he should be told what was in the bottle, and all the important factors which were of interest to him about what was in the bottle. ${ }^{40}$

As the agency authorized by the FAA Act to promulgate regulations furthering the Act, the Bureau of Alcohol, Tobacco and Firearms decided that it would regulate labels such that they "convey[] no erroneous impressions as to the age, origin, identity, or other characteristics of the product." 41 Thus, under the FAA Act, 27 U.S.C. $\S 205$ (e)-(f), and its implementing regulations, 27 C.F.R. $\S \S 4.39,4.64$, ATF has the authority to issue regulations "intended to prevent deception of the consumer, to provide the consumer with adequate information as to the identity and quality of the product, and to prohibit false or misleading statements." 42 Government endorsement of wine, organoleptic ${ }^{43}$ or otherwise, in labeling or in any other manner is specifically prohibited. ${ }^{44}$ A recent ATF labeling decision explained:

The purpose of the labeling provisions of the FAA Act is to prevent deception of the consumer and to provide the consumer with

39. Adolph Coors Co. v. Brady, 944 F.2d 1543, 1547 (10th Cir. 1991).

40. H.R. ReP. No. 74-1542, at 10 (1935).

41. 27 C.F.R. $\$ 4.33$ (b) (2000).

42. Labeling and Advertising Regulations Under the Federal Alcohol Administration Act, 49 Fed. Reg. 31,667, 31,668 (Aug. 8, 1984).

43. Organoleptic means "being, affecting, or relating to qualities (as taste, color, odor, and feel) of a substance (as a food or drug) that stimulate the sense organs." MERRIAM-WEBSTER's ColleGiate DicTiONARY 819 (10th ed. 1999).

44. Each ATF Final Rule establishing a new viticultural area contains a disclaimer to this effect. For example, ATF's Final Rule establishing the Yountville Viticultural Area:

The establishment of a viticultural area is neither an endorsement nor approval by ATF of the quality of wine produced in the area, but rather an identification of an area that is distinct from surrounding areas. ATF believes that the establishment of viticultural areas merely allows wineries to more accurately describe the origin of their wines to consumers, and helps consumers identify the wines they purchase. Thus, any benefit derived from the use of a viticultural area name is the result of the proprietor's own efforts and consumer acceptance of wines from the region.

Yountville Viticultural Area, 64 Fed. Reg. 13,511, 13,513 (Mar. 19, 1999). 
adequate information as to the identity and quality of the product. In prescribing regulations, ATF has the responsibility to ensure that the statutory goals are met.... ATF believes that we should regulate only where necessary and to the extent required to avoid consumer deception or provide the consumer with adequate information about the product. ${ }^{45}$

The fundamental purposes of ATF's effort, and all regulatory efforts worldwide, to protect geographical indications, are nearly identical to the purposes for protecting trademarks. Like geographical indications, trademarks are marketing tools whose use is regulated to protect consumers from fraud and to protect the economic interests of producers. ${ }^{46} \mathrm{Geo}-$ graphical indications, however, differ from trademarks in at least one key respect: geographical indications, by definition, serve to distinguish producers in one region from those in another region; tradeinarks, on the other hand, serve to distinguish one producer from another, regardless of location. ${ }^{47}$

Like the FAA Act, the Lanham Trade-Mark Act ("Lanham Act") of $1946^{48}$ also has the intent of rooting out "deceptive and misleading use of marks in such commerce."49 Under the Act, the basic test for trademark infringeinent is the likelihood of consumer confusion. ${ }^{50}$ Trademarks are classified according to a spectrum of distinctiveness, with the most distinctive (fanciful, arbitrary, and suggestive terms) being the most readily protected, and the least distinctive (generic terms) being unprotectable as tradeınarks. $^{51} \mathrm{~A}$ term that primarily describes a geographic origin of a product is descriptive, and thus falls in the middle of the distinctiveness spectrum. ${ }^{52}$ Ordinarily such geographically descriptive terms are not entitled to tradeinark protection because they are not distinctive enough to

45. Labeling of Flavored Wine Products, 65 Fed. Reg. 59,718, 59,723 (Oct. 6, 2000).

46. See Robert P. Merges, Peter S. Menell \& Mark A. Lemley, Intellectual Property IN THE NEw TECHNOLOGICAL AGE 559 ( $2 \mathrm{~d}$ ed. 2000) ("[T] he fundamental principles of trademark law have essentially been ones of tort: the tort of misappropriation of the goodwill of the trademark owner, and the tort of deception of the consumer.") (footnote omitted).

47. Geographical indications and trademarks therefore also might communicate different information to the consumer. A consumer presumably understands that a product nnay be produced by any business in the region identified by the geographical indication. The geographic term may describe not only the product's geographic origin, but also might connote specific qualities, features, or characteristics associated with similar products from that location, regardless of the individual identity of their producer.

48. Codified at 15 U.S.C. $\$ \$ 1051-1127$ (1994).

49. 15 U.S.C. $\$ 1121$ (1994).

50. See, e.g., AMF Inc. v. Sleekcraft Boats, 599 F.2d 341 (9th Cir. 1979).

51. See J. Thomas McCarthy, Trademarks and Unfair Competrtion $\$ 11: 1$ (4th ed. 1996); see also Zatarains, Inc. v. Oak Grove Sinokehouse, Inc., 698 F.2d 786 (5th Cir. 1983) (applying the spectrun of distinctiveness to determine the protectability of a mark).

52. See McCARTHY, supra note 51 , at $\S 14: 1$. The spectrum, from most to lcast distinctive, includes marks described as fanciful terms, arbitrary terms, suggestive terms, descriptive terms, and generic terms. Id. \$11:1. 
warrant exclusion of their use by others. ${ }^{53}$ They can be entitled to protection only upon a showing that they have "become distinctive of the applicant's goods in commerce"; 54 that is, the term has acquired a secondary meaning beyond its primary geographically descriptive meaning. ${ }^{55}$ Protection of geographically descriptive marks is always limited by the good faith "fair use" of that geographic term by others, in a nontrademark manner, merely to describe the geographic origin of their product. ${ }^{56}$

In recent years, trademark law has expanded to grant trademark protection beyond that provided by the likelihood of confusion test. This additional protection is against "dilution" of famous marks so that the use of a mark by another will gradually diminish the distinctive value of a famous mark, even in the absence of consumer confusion. ${ }^{57}$ Though dilution shares a common purpose with the confusion test, these two regulatory schemes have the potential to conflict whenever ATF places limits on the use of a geographic term on a wine label. Part III of this Comment borrows the consumer confusion and dilution analyses of trademark law and applies them to the regulation of geographic terms on wine labels to illustrate the shortcomings of ATF's current regulatory regime. The following Section presents ATF's current regulatory regime and traces the historical interaction between trademark law and ATF's labeling authority.

53. See 15 U.S.C. $\$ 1052(e)(2)$ (1994 \& Supp. V 2000) (refusing registration on the principal register of marks that are "primarily geographically descriptive" of the goods on which they are used). Descriptive terms are not protected because they are not distinctive enough to warrant exclusion of the use of such terms by others. Geographic terms may be arbitrary or fanciful in some cases as well. With respect to wine, this is no longer the case. See discussion supra Part 11.B.5.

54. 15 U.S.C. $\$ 1052(\mathrm{f})$ (1994 \& Supp. V 2000) (providing that descriptive marks may bc registered if they have "become distinctive of the applicant's goods in commerce").

55. The Supreme Court described this possibility in Le Republique Française v. Saratoga Vichy Spring Co.:

[G]eographical names often acquire a secondary signification indicative not only of the place of manufacture or production, but of the name of the manufacturer or producer and the excellence of the thing manufacturcd or produced, which enables the owner to assert an exclusive right to such name as against everyone not doing business within the same geographical limits....

191 U.S. 427, 435 (1903).

56. Lanham Act $\S 33(b)(4)$ recognizes the fair use defense: "[T]he use of the name, term, or device charged to be an infringement is a use, otherwise than as a mark . . . of a term or device which is descriptive of and used fairly and in good faith only to describe the goods or services of such party." 15 U.S.C. $§ 1115$ (b)(4) (1994).

57. The injury caused by "dilution" has been summarized as follows:

Dilution is an injury that differs materially from that arising out of the orthodox confusion.

Even in the absence of confusion, the potency of a mark may be debilitated by another's use. This is the essence of dilution. Confusion leads to immediate injury, while dilution is an infection which, if allowed to spread, will inevitably destroy the advertising value of the mark.

Mortellito v. Nina of California, Inc., 335 F. Supp. 1288, 1296 (S.D.N.Y. 1972) (citation omitted). 


\section{B. Use of Geographic References on American Wine Labels: The Regulatory Landscape}

For nearly fifty years following the repeal of Prohibition, ${ }^{58}$ geographic references were used on American wine labels with little or no formal definition of the geographic boundaries these references were meant to indicate..$^{59}$ In the mid-1970s, premium varietal wines ${ }^{60}$ began to take a share of the domestic U.S. wine market, once dominated by sales of generic and jug wines. ${ }^{61}$ Since 1978, ATF has required varietal wines to be labeled with an appellation of origin. ${ }^{62}$ Accordingly, the use of geographic references, both political ${ }^{63}$ and nonpolitical, ${ }^{64}$ proliferated on American wine labels.

58. U.S. CoNST. amend. XXI.

59. See Labeling and Advertising Rule, supra note 38, at 37,673 (describing its initial attempt to define wine-labeling terms "which have been used with little or no definition for decades"). In fact, the original regulation issued under the FAA Act in 1935 addressed geographic brand names in Regulation No. 4, Article IIl, $\S 33(\mathrm{~b})$. This regulation required that a label bearing the geographical indication of origin must have the word "brand" in direct conjunction with, and in one-half the size of, the brand name itself, unless at least $75 \%$ of the volume of the wine so labeled was derived from grapes grown and fermented in the area indicated by the brand name. In 1938, FAA Amendment No. 2 was published, crcating a distinct regulation entitled "Appellation of Origin" that provided that to be entitled to bear an appellation of origin, at least $75 \%$ of the wine's volumc had to be derived from fruit grown in the place indicated by such appellation, but set forth no guidelines for how precisely to delineate the boundaries of such appellations. This regulation also amended $\$ 33(\mathrm{~b})$ to require that if a brand name was found to be misleading, then the word "brand" had to appear in conjunction with the brand name; the amendment, however, did not specifically require all geographic brand names to appear in conjunction with the term "brand."

60. Varietal wines are those wines labeled with a specific grape variety, such as Cabernet Sauviguon, Chardonnay, Sauvignon Blanc, and Zinfandel. A comprehensive list of approved grape variety names is incorporated in ATF regulations. See 27 C.F.R. $\$ \S 4.91-4.93$ (2000). Premium wines normally are also varietal wines. The category of premium wines is defined by price per 750 milliliter bottle. Premium wines are those sold for three dollars or more per $\mathbf{7 5 0}$ milliliter bottle. Wines sold for less than three dollars are called "jug" wines. See Taylor, supra note 33, at 16.

61. See OXFord COMPANION To WINE, supra note 9, at 177:

As both consumers and trade matured in the 1970 s, there was a proliferation of California wineries specializing in just two or three wines, most of them labeled as varietal wines closely tied to their region of origin, a distinct step up from the generic wines that had dominated the state's production since Prohibition.

See also Pierre Spahin, The International Wine Trade 67 (1995). California wines account for over $90 \%$ of all U.S. wine production, and $72 \%$ of all U.S. wine sales. See Key Facts: California Wine Industry Statistical Highlights, at http:/www.wineinstitute.org/communications/statistics/stathi98.htm. In 1980 , jug wines accounted for $90 \%$, by volume, of all California wines sold in the U.S. market. By 1990 , this number had fallen to $70 \%$. By 1995 , jug wines accounted for only $59 \%$. See Taylor, supra note 33 , at 16 . Today, jug wines account for only $44 \%$ by volume, and only $17 \%$ by revenue. Premium wines, accordingly, account for $56 \%$ by volume and $83 \%$ by revenue. See 1999 California Wine Sales Reach Record High, Estimated 1999 Califomia Table Wine Shipments by Price Seginent, at http://www.wineinstitute.org/communications/statistics/sales $99 . \mathrm{htm}$.

62. See infra note 71 and accompanying text.

63. Political geographic references include city, county, state, or country names.

64. Nonpohitical geographic references included terms such as Willamette Valley, North Coast, Sonoma Valley, and Russian River Valley, whose boundaries, at that time, were not precisely defined in any legal sense. 


\section{ATF's Original Policy: The 1978 Comprehensive Appellation of Origin Labeling Scheme}

In 1978 , ATF responded to the changes in the wine industry by promulgating a "comprehensive scheme for appellation of origin labeling." 65 The scheme was an effort to "promote new markets for American wines" and to "inform consumers of those things that are important to them." simply, with regard to geographical indications, this scheme establishes (1) procedures for interested parties to petition for the creation of delimited grape growing areas, dubbed American Viticultural Areas ("AVAs"); ${ }^{67}$ (2) criteria to be used by ATF in drawing boundaries for AVAs; ${ }^{68}$ and (3) minimum requirements for the percentage of wine derived from grapes grown within an approved AVA (85\%), ${ }^{69}$ or a county, state, or country $(75 \%),{ }^{70}$ that must be met in order to label a wine with that particular geographic reference. These basic elements of the scheme have remained unchanged since 1978.

The 1978 scheme also addressed the interaction between the different components of a wine label. Then, as today, a typical premium wine label conveys to the consumer four main pieces of information: a producer or brand name (for example, Gallo); a grape variety name (for example, Chardonnay); a geographic origin of the grapes (for example, Sonoma Valley); and the vintage year (for example, 1998). The 1978 regulations addressed the use of each of these label elements. The 1978 scheme not only created the basic appellation of origin and AVA labeling system that controls use of geographical indications of origin, but required that a wine be labeled with an appellation of origin in order to be labeled with a varietal name. ${ }^{71}$ The 1978 Final Rule examined and ultimately affirmed the preexisting controls on use of vintage years on labels. ${ }^{72}$ The labeling scheme,

65. Labeling and Advertising Rule, supra note 38, at 37,672. The term "appellation of origin," as used throughout this paper, should not be confused with the French term "appellation d'origin controlée" ("AOC"). The French AOC regulations contain stringent quality controls, unlike the American system described in this Section. Rather, the term "appellation of origin" is used, as defined in 27 C.F.R. $\$ 4.25$ a(a) (2000), to denote the types of geographical indications of origin that can appear on American wines: United States, state name(s), county name(s), or viticultural area name. See infra Part 1I.B.

66. Labeling and Advertising Rule, supra note 38, at 37,672.

67. See 27 C.F.R. $\$ 4.25 \mathrm{a}(\mathrm{e})(2)(2000)$.

68. See id.

69. Eighty-five percent of a wine must be derived from a single AVA in order to label that wine with that AVA name. 27 C.F.R. $\$ 4.25$ a(e)(3)(ii) (2000).

70. Seventy-five percent of a wine must be derived from a single state or county in order to label that wine with that state or county name. 27 C.F.R. $\$ 4.25 \mathrm{a}(\mathrm{b})(1)(\mathrm{i})(2000)$.

71. See Labeling and Advertising Rule, supra note 38, at 37,674 (codified at 27 C.F.R. $\S 4.23(a)$ ). To be labeled with a grape varietal name, tbe wine must derive from at least $75 \%$ of grapes of that single variety, the entire $75 \%$ of which must be grown in the labeled appellation of origin. 27 C.F.R. 4.23(a),(b) (2001).

72. See Labeling and Advertising Rule, supra note 38, at 37,673. 
as originally formulated, also contemplated the issue that is the subject of this Comment: conflicts between geographical indications of origin and brand names. As this Comment will argue in Part III, ATF, for the nost part, established an appropriate scheme in 1978.

The 1978 scheme took a restrictive, yet discretionary, approach to the issue of brand names with "geographic significance" in an attempt to minimize consumer confusion. Under ATF regulations, brand names of "viticultural significance" are those that incorporate the name of a state, county, or AVA, or foreigu equivalent, or those found to have viticultural significance by the ATF Director. ${ }^{73}$ ATF's original 1978 approach to conflicts between such brand names and regulated geographic references was to limit such brand names to use only with wines that met two criteria: the winery that produced the wine had to be located within the geographic area named in the brand name, and the wine had to meet the grape origin percentage requirements for the geographic area named. ${ }^{74}$ Alternatively, a wine could be labeled with a brand name of geographic significance if the word "brand" immediately followed the brand name in the same size typeface and was as conspicuous as the brand name itself. ${ }^{75}$

ATF designed its 1978 rule to minimize consumer confusion in the use of brand names with geographic significance. Had it remained unchanged, it may have proved too restrictive in one respect. It is a very common practice for wineries to produce wines sourced from vineyards in different regions, even those well outside the region where the winery is located. Thus, the requirement that the winery be located within the region indicated by the brand name may have proven unworkable and was later removed, as is discussed in the following Section. The remaining labeling requirements, had they remained intact, would have effectively served the core purposes of ATF's coinprehensive labeling scheme. ${ }^{76}$

\section{ATF's 1986 Revisions and Current Labeling Policy: The Grandfathering Provision}

The original mandatory compliance date for the appellation of origin and brand name provisions of ATF's 1978 labeling scheme was January 1 ,

\footnotetext{
73. 27 C.F.R. 4.39(i) (1979).

74. See supra notes $69-70$.

75. 27 C.F.R. 4.39(i) (1979). ATF envisioned this rule operating such that

if the Director [found] that because of long usage such [brand] names [of geographic significance] are recognized by consuiners as fanciful product names and not representations of origin, he may permit continued use of such name, even though the product does not originate in the named geographical area, if the word "brand" is prominently displayed immediately following the product name. In addition, the Director [might] require that the label of such product bcar a statement disclaiming the geographical reference as a representation of the origin of the wine.
}

Labeling and Advertising Rule, supra note 38, at 37,674.

76. See infra Part II1. 
1983. ${ }^{77}$ ATF delayed implementation of these provisions for two years, after a lawsuit brought by three "sophisticated wine consumers" in the District Court of the District of Columbia cast doubt upon the validity of the regulations. ${ }^{78}$ The suit alleged that the new policies were invalid under the FAA Act because they "indulge[d] wineries in statements not wholly accurate. It is deceptive, they said, for a winery to . . . represent that a wine comes from Napa Valley when only 85 percent of its grapes were grown there ... ."79 On appeal, the Court of Appeals for the D.C. Circuit held that the grape wine-labeling regulations in question could not be upheld, and remanded them to ATF to afford it an opportunity to show that such regulations would meaningfully control misleading labeling and advertising. ${ }^{80}$ Forced to re-examine their regulations in 1984, ATF proposed a new rule, stating that it "believe[d] the current regulation [on geographic brand names] may be too restrictive and constrains creativity in selecting brand names."

In 1986, ATF issued its Final Rule, with two major changes to its policy on geographic brand names. ${ }^{82}$ First, ATF removed the requirement that a winery with a geographic brand name be located within the appellation described by the name. ${ }^{83}$ This change was necessary to square with the realities of the production process; many wineries, even those that produce wines derived from multiple, geographically distant sources, consolidate their production in as few locations as possible. Second, the Final Rule incorporated a highly permissive approach to use of pre-existing geographic brand names. ATF adopted the following policy, which remains its current policy: if a brand name incorporates the name of a state, county, or AVA, or is otherwise found to have viticultural significance by the ATF Director, that wine must comply with the appellation requirements for the area named. ${ }^{84}$ There is one exception: brand names that were used in approved labels issued prior to July 7, 1986 (the effective date of the amended regulations) are "grandfathered." Thus they are entitled to remain in use so long as the label also discloses an appropriate, true appellation of origin for the wine, or some other label statement, approved by the Director of ATF, that dispels any consumer confusion about the origin of the grapes. ${ }^{85}$ Grandfathered geographic brand names that incorporate the name of an area

77. See 27 C.F.R. $\$ \S 4.25$ a, 4.26, 4.39(i)-(j) (1978).

78. Wawszkiewicz v. Dep't of Treasury, 480 F. Supp 739, 741 (D.D.C. 1979), affd, Wawszkiewicz v. Dep't of Treasury, 670 F.2d 296 (D.C. Cir. 1981) (per curiam).

79. Wawszkiewicz, 670 F.2d at 300.

80. Id. at 304.

81. Use of Geographic Brand Names, 49 Fed. Reg. 19,330, 19,331 (proposed May 7, 1984).

82. Wine Labeling and Advertising; Use of Geographic Brand Names, 51 Fed. Reg. 20,480 (June

$5,1986)$.

83. Id. at 20,482 .

84. 27 C.F.R. $\$ 4.39$ (i) (2000).

85. Id. 
smaller than a state must be labeled with a county or AVA appellation of origin. $^{86}$ This grandfathering exception is seriously flawed, as will be discussed in detail in Part III.

\section{Creation of $A V A s$ and $A T F$ 's Nondeference to Trademark Rights}

To date, ATF has approved 145 AVAs in twenty-eight states. The criteria for establishment of an AVA are broad and interpreted at ATF's discretion. There is no prescribed minimum or maximum size for a viticultural area, and they range in size from the very large (for example, the 16.6 million acre Ohio River Valley AVA that spans parts of four states) ${ }^{87}$ to the very small (for example, the 150 acre Cole Ranch AVA in California). ${ }^{88}$ There is also no prescribed order for their creation. Some smaller AVAs have been created within pre-existing larger viticultural areas, ${ }^{89}$ while $\mathrm{m}$ other instances, large viticultural areas have been formed around pre-existing smaller AVAs. ${ }^{90}$ While one of the three main criteria for establishment of a viticultural area is that there be "[e]vidence that the name of the viticultural area is locally and/or nationally known as referring to the area specified in the application," show any deference to the rights of existing holders of homonymous or identical trademarks that may be locally or nationally known as referring to an individual producer's wine products. ${ }^{92}$ Registration of a name with the U.S. Patent and Trademark Office might be relevant to the name recognition criterion, but such registration is not the basis for establishing, or declining to establish, AVA boundaries.

When the issue of a conflict between a proposed AVA name and an established brand name first arose, ATF averted a conflict with a trademark holder who was opposed to the creation of the viticultural area. In 1979, Chalone Winery petitioned for the creation of an AVA in Monterey and

86. Id.

87. See 27 C.F.R. $\$ 9.78(2000)$.

88. See 27 C.F.R. $\$ 9.42(2000)$.

89. For example, the Napa Valley AVA was established in 1981. See 27 C.F.R. $\$ 9.23$ (2000). Since that time, eleven AVAs whose boundaries lie wholly within the Napa Valley AVA have been created: Howell Mountain (1984), Stags Leap District (1989), Mt. Veeder (1990), Atlas Peak (1992), Rutherford (1993), Oakville (1993), Spring Mountain District (1993), St. Helena (1995), Chiles Valley (1999), Yountville (1999), and Diamond Mountain (2001). See 27 C.F.R. $\$ \$ 9.94,9.117,9.123,9.133$, $9.134,9.140,9.143,9.149,9.154,9.160,9.166$ (2001). Two other viticultural areas, Wild Horse Valley and Carneros, lie partially within the Napa Valley AVA. See 27 C.F.R. $\$ \$ 9.124,9.32$ (2000).

90. For example, the San Benito AVA in California, when established, contained within it the previously approved Paicines, Cienega Valley, and Lime Kiln Valley viticultural areas. See Establishment of Viticultural Area; San Benito, 52 Fed. Reg. 37,135 (Oct. 5, 1987).

91. 27 C.F.R. $\$ 4.25 \mathrm{a}(\mathrm{e})(2)(\mathrm{i})(2000)$. In addition to providing a U.S.G.S. map showing the boundaries of the proposed area, an applicant must provide "[h]istorical or current evidence that the boundaries of the viticultural area are as specified in the applieation ... [and] evidence relating to the geographic features (climate, soil, elevation, physical features, etc.) which distinguish the viticultural features of the proposed area from surrounding areas." Id.

92. Id. 
San Benito Counties, California, to be known as "The Pinnacles." Nearby Paul Masson Winery was not within the proposed area and previously had registered its brand name "A Pinnacles Selection," along with "Pinnacles," as trademarks. ${ }^{94}$ ATF requested comments on alternative names after concluding that "the proposed name... was inappropriate... because of trademark claims by another winery and the possibility of consumer confusion that would result if the proposed name were approved." AVA was approved as "Chalone," identical to a registered trademark of the winery that had filed the original petition. ${ }^{96}$

In subsequent viticultural area rulemaking proceedings, perhaps as ATF has become more comfortable with its AVA regulations, it has acknowledged existing trademark and brand name conflicts, but has arrived at a firm position that the rights applicable to AVA names take precedence. ${ }^{97}$ For example, in 1989, ATF established the Wild Horse Valley AVA in Napa and Solano Counties of California despite claims by Santa Lucia Winery of Santa Barbara County, California, that it had pre-existing trademark rights to the term "Wild Horse." In its Final Rule on the Wild Horse Valley AVA, ATF summarized its position:

It is not the policy of ATF to become involved in purely private disputes involving proprietary rights, such as trademark infringement suits. However, in the event a direct conflict arises between some or all of the rights granted by a registered trademark under the Lanham Act and the right to use the name of a viticultural area established under the FAA Act, it is the position of ATF that the rights applicable to the viticultural area should control. ${ }^{99}$

AVAs describe the origin of a wine by a regional name, as historically known or nationally recognized. Thus, use of an AVA logically would qualify under trademark law as a fair use of a geographic term, describing the true geographic origin of a producer's product. For this reason, it is not surprising that ATF has taken a position that shows no deference to the

93. Chalone Viticultural Area, 47 Fed. Reg. 25,517 (June 14, 1982).

94. Id.

95. Id.

96. Id.

97. See, e.g., North Coast Viticultural Area, 48 Fed. Reg. 42,973, 42,976 (Sept. 21, 1983) (establishing the North Coast AVA over the objections of the California North Coast Grape Growers Association, which held a certifieation mark consisting of a seal and the legends "North Coast" and "Napa Sonoma-Mendocino"). See also Martha's Vineyard Viticultural Area, 50 Fed. Reg. 255 (Jan. 3, 1985) (establishing the Martha's Vineyard AVA in Massachusetts, based on clear evidence that the name was locally or nationally known as referring to the island off the coast of Massachusetts, and over the objection of Heitz Wine Cellars, maker of the well-known Heitz Wine Cellars Martha's Vineyard Cabernet Sauvignon, named after the grower's wife).

98. Wild Horse Valley Viticultural Area; California, 53 Fed. Reg. 48,244, 48,246 (Nov. 30, 1988).

99. Id. at 48,246 . 
rights of existing trademark holders; holders of a trademark containing a geographical indication would have no remedy against a wine producer using that same geographical indication as an AVA to describe the true origin of its wines.

\section{An Industry-Specific Lanham Act Provision}

Congress amended the Lanham Act in 1994 in an attempt to conform to several wine industry-specific provisions that resulted from the last round of world trade talks. The 1994 General Agreement on Tariffs and Trade ("GATT") included an agreement on "Trade Related Aspects of Intellectual Property Rights" ("TRIPs"). ${ }^{100}$ This Agreement expressly defined geographical indications on wimes and spirits as a form of intellectual property, and included numerous provisions designed to increase the protection of geographical imdications. ${ }^{101}$ Article 23.2 of TRIPs requires members to refuse or imvalidate registration for wine trademarks that contain false geographical indications. ${ }^{102}$

Since American regnlation with respect to the use of geographic terms on wine labels is subject to the Uinted States' international obligations, Congress amended the Lanham Act in an atteinpt to conform to GATT's geographical indication provision. ${ }^{103}$ The Lanham Act now prohibits registration on the principal register of any trademark that contains "a geographical indication which, when used on or in connection with wines or spirits, identifies a place other than the origin of the goods" and is first used on or after the effective date of the amendment. ${ }^{104}$ However, the Lanham Act does not provide any gnidance for how origin validity will be determined, especially where the geographic term is not an established AVA, state, or county name. Furthermore, if a trademark is not geographically deceptive when registered, there is nothing in the Act to allow for its cancellation if it later becomes deceptive. ${ }^{105}$ ATF, however, does have the right to deny or cancel label approvals, subject to procedural due process, if a geographic brand name is (or later becomes) deceiving. ${ }^{106}$

\footnotetext{
100. See TRIPs Agreement, supra note 18 .

101. See id. arts. 22-24.

102. Id. art. 23.2.

103. See Uruguay Round Agreements Act, Dec. 8, 1994, Pub. L. 103-465, 108 Stat. 4809.

104. Lanham Act $\$ 2$ (a), 15 U.S.C. $\$ 1052$ (a) (1994 \& Supp. V 2000).

105. See Consorzio del Prosciutto di Parma v. Parma Sausage Products Inc., 1992 WL 233379 (Trademark Tr. \& App. Bd. June 17, 1992) (holding that a mark's geographic deceptiveness must be established as of date on which registration was issued, not as of time of trial).

106. 27 CFR $\$ 13.41$ (2000). ATF recently published rules outlining its procedures for canceling label approvals. See Procedures for the Issuance, Denial, and Revocation of Certificates of Label Approval, Certificates of Exemption From Label Approval, and Distinctive Liquor Bottle Approvals, 64 Fed. Reg. 2122 (Jan. 13, 1999); Procedures for the Issuance, Denial, and Revocation of Certificates of Label Approval, Certificates of Exemption From Label Approval, and Distinctive Liquor Bottle Approvals; Correction, 64 Fed. Reg. 10,949 (Mar. 8, 1999).
} 
ATF has taken a public position that these amendments to the Lanham Act in no way change the relationship between ATF regulations and trademark law, and in no way preempt ATF's ability to regulate the use of pre-existing trademarks on wine. ${ }^{107}$ This relationship has been summarized by one court as follows:

A grant of a trademark by the governing agency is not a carte blanche to use the mark for any and all purposes. Implicit in such a grant is the obligation to use the trademark in compliance with other valid laws, even if, as a practical inatter, such laws limit the use of the trademark. The BATF's regulations do not nullify [the geographic trademark] - they merely put restrictions on wine which accounpanies the trademark. ${ }^{108}$

ATF's ability to regulate geographic terms on wine labels thus is not preempted by the Lanham Act, but exists as an additional regulatory authority with which a trademark holder inust comply.

\section{Additional Geographic References on Wine Labels}

Besides appearing as an appellation of origin or as part of a brand name, a geographic reference also may appear on a wine label in four other contexts: as a wine type designation; as a vineyard name; as a bottling trade name; or as a winery address.

First, under the FAA Act, ATF may establish "Standards of Identity for Wine," which includes several classes of wine, as well as types of wine within each class, defined according to characteristics including production method, ingredients, and alcohol content. ${ }^{109}$ Geographic terms have appeared as wine type designations, as part of grape variety names, and as a "generic" or "semi-generic" wine type. A geographic term may appear as part of a grape variety name. Grape variety names may be used as wine type designations, provided the variety name appears on a list of approved names. ${ }^{10}$ Several grape variety naines have traditionally incorporated geographic terms. These include Johannisberg Riesling, Napa Gamay, and Gamay Beaujolais. ${ }^{111}$ A geographic term has also appeared as a generic or semi-generic wine type. As defined by ATF, generic terms are geographic references that have lost their geographic significance and only describe a

107. Bronco Wine Co. v. U.S. Dep't of Treasury, 997 F. Supp. 1309, 1322 (E.D. Cal. 1996) (endorsing ATF's assertion and holding that the Uruguay Round Agreements Act makes it "abundantly clear ... that the Agreements and enabling legislation shall not be 'construed ... to amend or modify any law of the United States"') (quoting 19 U.S.C. $\$ 3512(a)(2)$ (Supp. V 2000)).

108. Id. at 1317 .

109. 27 C.F.R. $\$ 4.21$ (2000). For example, the classes of wine include "grape wine," "sparkling grape wine," and "carbonated grape wine." One wine type is "table wine," defined as a "grape wine having an alcoholic content not in excess of 14 percent by volume." 27 C.F.R. $\$ 4.21$ (a)(2) (2000).

110. See 27 C.F.R. $\$ 4.23$ (2000). The list of approved names is found at 27 C.F.R. $\$ 4.93(2000)$.

111. See infra Part III.B. 
type of wine. ${ }^{112}$ ATF gives two examples of such names: "Vermouth" and "Sake." "113 Generic wine types may appear on a wine label without any indication of origin. ${ }^{114}$ Semi-generic names are names that have retained their geographic significance, but also describe, in a generic sense, a type of wine. ${ }^{115}$ ATF gives sixteen examples of semi-generic terms that describe a wine type for purposes of American labeling. ${ }^{116}$ Fifteen of these terms are European in origin; ${ }^{117}$ among thein, some of Europe's most famous wine regions, including Champagne, Chablis, Burgundy, Sauterne, and Chianti. ${ }^{18}$ These terms may be used on wines derived from American grapes provided a true appellation of origin appears in conjunction with the semi-generic term. ${ }^{119}$

Second, a geographic term may appear as part of a vineyard, orchard, farm, or ranch name. ATF permits use on wine labels of vineyard, orchard, farm, or ranch names having viticultural or geographic significance if at least $95 \%$ of the wine's grapes come from the named vineyard. ${ }^{120}$ Unlike viticultural areas, however, vineyard boundaries are not formally defined by ATF.

Finally, a geographic term may appear on a wine label as part of a winery's bottling trade name or address. These generally appear on a back label as "Produced and bottled by Trade Name Winery, Name of City, Naine of State."121 ATF is less concerned about geographic bottling trade names than brand names because the brand name is typically the predominant feature on the label, ${ }^{122}$ and the bottling trade name must always appear in conjunction with the address of the producer, bottler, or packer. ${ }^{123}$ Thus, ATF does not require that bottling trade names or winery addresses correspond to or meet the appellation of origin requirements of the wine.

\section{The Current Political Ferment}

The issue of geographic terms on wine labels has recently been thrown into the political spotlight and the courtroom in California. Most of

112. See 27 C.F.R. $\$ 4.24$ (a) (2000).

113. Id.

114. Id.

115. See 27 C.F.R. $\$ 4.24$ (b) (2000).

116. See 27 C.F.R. $\$ 4.24$ (b) (2000). The sixteen semi-generic names are Angelica, Burgundy, Claret, Chablis, Champagne, Chianti, Malaga, Marsala, Madeira, Moselle, Port, Rhine Wine, Sauterne, Haut Sauterne, Sherry, and Tokay. Id.

117. The sixteenth, Angelica, is a geographic reference to Los Angeles.

118. 27 C.F.R. $\S 4.24(b)(2000)$.

119. See id.

120. See 27 C.F.R. $\$ 4.39(\mathrm{~m})(2000)$.

121. See 27 C.F.R. $\$ 4.35 \mathrm{a}(2000)$.

122. See Wine Labeling and Advertising; Use of Geographic Brand Names, 51 Fed. Reg. 20,480, 20,481 (June 5, 1986).

123. See 27 C.F.R. $\$ 4.35$ a (2000). 
the controversy has arisen from the actions of a single wine producer in California and the predictable response of affected producers.

\section{The Rutherford Vineyards Case}

Five years ago, an advertisement for a Rutherford Vineyards brand wine stated:

It's confusing. With so many labels laying claim to the Rutherford name, you can hardly tell a shrub from a vine. To clarify, consider this sprig of vintner wisdom. Good grapes ... make good wines. Simple enough. And you don't have to be a wise old wimemaker to know where grapes come from. ${ }^{124}$

Simple enough indeed. But this particular Rutherford Vimeyards wine was not from Rutherford. Instead, it was labeled with the "California" state appellation, in clear violation of 27 C.F.R. $\$ 4.39$ (i) because "Rutherford" is the name of an approved AVA, and the Rutherford Vineyards brand therefore must be labeled with a true county or AVA appellation of origin. ${ }^{125}$ After initially, and mistakenly, approving these labels, ATF seized and confiscated approximately 32,000 cases of this Rutherford Vineyards brand wine from its producer, Bronco Wine Company ("Bronco"). ${ }^{126}$

Bronco's subsequent suit against ATF raised industry awareness of the grandfathering provision of 27 C.F.R. $\$ 4.39$ (i). Bronco purchased the name rights to "Rutherford Vineyards" and "Rutherford Vintners," along with existing inventories, from their original user in Rutherford, ${ }^{127}$ a sinall town and AVA located in Napa County. The original owner of these names had used them historically only for wines originating in Napa County, a use properly within ATF regulations. Many vintners were alarmed by Bronco's success in purchasing rights to a geographic name and expanding its use to all AVAs and counties simply because the brand was in use prior to $1986 .{ }^{128}$ There are dozens of these grandfathered geographic brand names that incorporate approved AVA names and whose use could be expanded in a similar manner. ${ }^{129}$

124. See Appendix A. This full-page advertisement appeared at least six times in Wine Enthusiast magazine in 1996. The Merlot version shown in Appendix A, or a Chardonnay version with identical text and format and slightly different background artwork, appeared in the May, June, July, September, October, and November 1996 issues of Wine Enthusiast.

125. See 27 C.F.R. $\S 9.133$ (2000) (stating that a grandfathered geographic brand name that incorporates the name of an area smaller than a state must be labeled with a county or AVA appellation of origin).

126. See Bronco Wine Co. v. U.S. Dep't of Treasury, 997 F. Supp. 1309, 1310 (E.D. Cal. 1996).

127. See Peter Sinton, Bronco Wine's Premium Buy; Rutherford Joins Its Stable, S.F. CHRON., Aug. 24, 1994, at B1; see also Wine Institute, Geographic Brand Names: The White Paper 2122 (Oct. 26, 1999) [hereinafter WHITE PAPER].

128. See WhITE PAPER, supra note 127 , at 22.

129. See id. 


\section{Lack of Foreseeable Industry Consensus}

The California wine industry recognized that a problem existed. In 1996, the Wine Institute, a California wine industry trade association whose membership of over 500 wineries and affiliated businesses includes the major California wineries and hundreds of smaller wineries, formed a Subcommittee on Geographic Brand Names and informed ATF that it would commence a review of geographic brand names and their impact on intellectual property rights. ${ }^{130}$ The Wine Institute's attempt to craft a common position to present to ATF ultimately failed. The inability to reach consensus can be attributed to the highly concentrated, yet fragmented, nature of the industry and the divergence in commercial interests among industry participants. Smaller-quantity, higher-margin producers in wellknown regions and higher-quantity, lower-margin producers in less-wellknown regions do not appear to share a common philosophy with respect to geographical indications with those in more well-known regions placing greater emphasis on the origin of their products and on geographical indications in general. ${ }^{131}$ While the Wine Institute continues to study this issue, there is no foreseeable consensus.

\section{California's Stopgap Solution for Napa County and the Industry's Response}

Bronco Wine Company purchased the Napa Ridge brand name and related assets from Beringer Wine Estates in 2000 for approximately forty million dollars. ${ }^{132}$ Bronco's brand portfolio now includes Napa Ridge, Rutherford Vintuers, Rutherford Vineyards, and Napa Creek Winery, among others. ${ }^{133}$ Earlier, in 1999, a company related to Bronco Wine Company obtained a permit to build and began construction on an immense bottling facility in an industrial park in southern Napa County, ${ }^{134}$ an area unaffected by a local regulation that requires new wineries to source $75 \%$ of their grapes from Napa County. ${ }^{135}$ This facility, now built, is designed to bottle up to $17,840,400$ cases of wine annually, ${ }^{136}$ more than

130. See id. at 3.

131. See id. at 23. See also supra note 21.

132. See Beringer Wine Estates Holdings, Inc., Quarterly Report for Period Ending DEc. 31, 1999 (Feb. 15, 2000), available at http://www.sec.gov/Archives/edgar/data/ 1041891/0000898430-00-000488-index.html.

133. See id.; see also Sinton, supra note 127.

134. This use permit was obtained by Barrel Ten Quarter Circle, Inc. lts use permit application was signed by the president of Bronco Wine Company, as co-president and treasurer of Barrel Ten. See Napa County Conservation-Development \& Planning Commission, Use Permit Application, File No. 98,068-UP.

135. NaPA CountY, CaL., Code $\S 18.104 .250$ (1993) contains this requirement, but it applies only to areas zoned for agricultural use. The Barrel Ten facility is located in an area zoned industrial and is thus not covered by the local regulation.

136. See Use Permit Application, supra note 134. 
the entire annual production potential of Napa County's roughly 31,000 acres of wine grapes. ${ }^{137}$

The Napa County wine industry feared that Bronco or its affiliates would bottle this massive quantity of wine, nnder its several geographic brand names that make reference to Napa or the AVAs within Napa County. It would also have the added presence on the label of a Napa bottling address. ${ }^{138}$ Recognizing that consumer confusion and dilution would almost certainly result, the Napa Valley Vintners Association ("NVVA") in 2000 successfully lobbied for the passage of a California law designed to protect the name "Napa" as well as the names of the other AVAs in Napa County. The law requires wines labeled with the name "Napa," the name of any AVA located wholly within Napa County, or any other confusingly similar name, ${ }^{139}$ to qualify for the appellation of origin Napa County..$^{140}$ That is, wine labeled or advertised using such geographic names, in a brand name or otherwise, must derive at least $75 \%$ of its content from grapes grown in Napa County. ${ }^{141}$ This statute applies to all wines "produced, bottled, labeled, offered for sale or sold in California," and provides for revocation or suspension of the state license of any winery or producer if found in violation. ${ }^{142}$ The California law is a stopgap measure, ${ }^{143}$ applicable to wines produced, bottled, marketed, or sold in California, that annuls the grandfathering provision of 27 C.F.R. § 4.39(i) with respect to geographic brand names associated with Napa County. When signing this bill into law, California Governor Gray Davis stated: "This legislation will end deceptive marketing, and protect the reputation of Napa Valley wines."144

Not surprisingly, Bronco Wine Company requested, and was granted, an injunction against enforcement of the new law, arguing that it is unconstitutional because it restricts the company's free-speech and commercialspeech rights, bars the use of labels already approved by federal regnlators,

137. See Napa County Dep't of Agric., Cal. Dep't of Food and Agric., 1999 Crop Report 1 (Apr. 25, 2000).

138. See, e.g., Yochi Dreazen, Beverages: Just What's in a Bottle of 'Napa' Wine Uncorks a Feud, Wall Sr. J., July 7, 1999, at B1; Gerald D. Boyd, Vintners Angry over Use of 'Napa' on Some Wine Labels, S.F. CHRON., Jan. 19, 2000, Food 6. It is troubling, however, that there was no vociferous opposition from the Napa Valley Vintners Association during Beringer Wine Estates's longstanding use of the Napa Ridge brand with wines originating from outside the Napa Valley.

139. Perhaps in response to the Napa Valley Vintners Association's success in lobbying against confusing use of geographic brand names, Bronco Wine Company applied to register the confusingly similar trademarks "Nava Ridge" and "NVVA Ridge" with the U.S. Patent and Trademark Office. See U.S. Patent and Trademark Office, Trademark Application, Serial Nos. 76128760, 76128761.

140. Cal. Bus. \& Prof. Code $\$ 25241$ (West Supp. 2001).

141. Under 27 C.F.R. $\$ 4.25$ a (2000), a wine must derive at least $75 \%$ of its content from Napa County to qualify for the appellation of origin Napa County.

142. Cal. Bus. \& Prof. Code $\$ 25241$ (b) (West Supp. 2001).

143. James Laube, A Stopgap Proposal, Wine Spectator, June 30, 1999, at 31.

144. Press Release, Office of the Governor, State of California, Governor Davis Signs Napa Wine Legislation (Sept. 28, 2000) (on file with author). 
singles out Bronco products, tries to supersede federal statutes, and diminishes the value of some of the company's brand names. ${ }^{145}$ The case has yet to be tried on its merits. A decision is expected in December 2001 or January 2002.

The California bill did not have unanimous support in the premium wine industry. Many producers, notably many of those in Sonoma County, and some industry commentators expressed their desire that this issue be resolved at the federal level to protect all wine-growing regions under a uniform regulatory scheme. ${ }^{146}$

\section{III \\ Nonconforming Uses of Geographic References on AmERICAN Wine LABELS}

\section{A. ATF's Wine-labeling Scheme: A Zoning Plan for Geographic Terms}

When ATF promulgated its comprehensive wine-labeling scheme in 1978, it created a comprehensive zoning plan for the use of geographic terms and other product identifiers on wine labels. In land-use regulation, a comprehensive plan is a statement of a municipality's objectives and standards for development. ${ }^{147}$ These objectives often are embodied in a zoning scheme that divides the municipality into districts and regulates the nature and extent of property uses according to its location. ${ }^{148}$ Similarly, ATF's wine-labeling scheme is a statement of the department's objectives for wime-labeling practices and its standards of development for the use of product identifiers on wine labels. ATF's objectives are embodied in a type of zoning scheme that divides the country into appellations of origin and regulates the use of geographic terms on wine labels according to the vineyard location of the grapes from which a wine derives. ${ }^{149}$

A municipal zoning plan, like ATF's wine-labeling plan, is a forwardlooking policy because future uses necessarily can be prohibited under a zoning ordinance. ${ }^{150}$ When a zoning ordinance is enacted, it generally allows for a number of pre-existing lawful uses that do not comply with the

145. See Bronco Wine Company, supra note 2.

146. See, e.g., Rone Tempest, California and the West; Would a Wine without Label Have Bouquet?; Trademark: A Grower Wants to Use the Napa Nante on Grapes from Elsewhere. Valley Winemakers Seek a Law to Stop Him, L.A. Tmes, Aug. 13, 2000, at A33. The Sonoma Valley Vintners and Growers Alliance did not jom the Napa Valley Vintners Association in lobbying for the passage of CAL. Bus. \& Prof. Code $\$ 25241$, supra note 140.

147. See, e.g., CAL. Gov'T CODE $\$ 65302$ (West 1997) (setting forth the required elements of a California municipality's "general plan").

148. See, e.g., CAL. Gov'T CODE $\$ 65850$ (West 1997) (granting municipalities the authority to regulate the use of property under a zoning plan).

149. See supra Part II.B.1-2.

150. See, e.g., State v. Joyner, 208 S.E.2d 233, 236 (N.C. Ct. App. 1974) (stating that "future uses clearly can be prohibited under zoning ordinances"). 
newly created use restrictions. ${ }^{151}$ Such uses are referred to as "nonconforming uses." 152 ATF's "comprehensive scheme for appellation of origin labeling" 153 similarly encompasses a number of uses that do not comply with either its general plan or the use restrictions generally applicable to geographic terms. These "nonconforming uses" are described in the next Section.

\section{B. Nonconforming Uses Under ATF's Wine-labeling Scheme}

Some uses of geographic terms on wine labels, while technically not violating any specific provisions, fail to comport with ATF's general plan to ensure that such terms indicate the region in which the wine was grown. ${ }^{154}$ The core of this general plan is codified at 27 C.F.R. $\S 4.25 \mathrm{a}$, which sets forth the basic requirements for appellation of origin labeling as described in Part II.B above. The nonconforming uses of geographic terms under ATF regulations include grandfathered geographic brand names, ${ }^{155}$ semi-generic wine type names, varietal names of geographic or viticultural significance, and geographic bottling trade names, none of which necessarily reflect the region in which the wine was grown. ${ }^{156}$ Thus, "conformity" in the use of geographic terms on wine labels, for the purposes of this Comment, embodies the simple notion that a wine originates in the region indicated on its wine label.

Initially, ATF prohibited the nonconforming use of geographic brand names unless they were conspicuously accompanied by the term "brand." "I57 In 1986, by amending its regulations to include a grandfathering provision applicable to marks that pre-dated the amended regulations, ${ }^{158}$ ATF created a legal nonconformity in the use of geographic terms on wine labels. Those geographic marks that existed prior to the grandfathering date of July 7, 1986, are not required to comply with the limitations placed on the use of geographic brand names first used after that date. ${ }^{159}$ Grandfathered brand names must be accompanied by a true appellation of origin, but common labeling practices for such brand names place great emphasis

151. See, e.g., Hill v. Manhattan Beach, 491 P.2d 369 (1971); In re Miller, 482 A.2d 688, 690-91 (Pa. 1984) (citation omitted) ("[A] nonconforming use is one which does not comply with present zoning provisions but which existed lawfully and was created in good faith prior to the enactment of the zoning provision.").

152. Miller, 482 A.2d at $690-91$.

153. Labeling and Advertising Rule, supra note 38 , at 37,672 .

154. See discussion supra Part II.B.1-2.

155. See 27 C.F.R. \$ 4.39(i) (2000); see also discussion supra Part 11.B.2.

156. See discussion supra Part II.B.4. The use of the term "nonconforming" throughout this Comment is not meant to imply that such uses are illegal. They are legal under current ATF regulations. This Comment refers to them as nonconforming because they do not fit with what this Comment describes as ATF's general plan for wine labeling.

157. See 27 C.F.R. \$ 4.39(i) (1979).

158. See 27 C.F.R. \$ 4.39(i) (2000); see also discussion supra Part 11.B.2.

159. See id. 
on the brand name while noting the true appellation of origin in less conspicuous typeface and location.

ATF made no provisions for the eventual termination of this type of nonconforming use, placed no constraints on the production volumes such wines could achieve, required no continuous use of grandfathered brand names, and required no congruity between historical and future use of a brand name in association with specific appellations. ${ }^{160}$ Thus, under $\S 4.39(\mathrm{i})$, a hypothetical Carmel Valley Caves brand name, which historically had only been used in association with the Carmel Valley AVA and which may have been out of use for several years, could be sold to a producer ${ }^{161}$ who could use the brand on unrestricted volumes of wine from any origin, provided the wine was labeled with a true county or AVA appellation of origin. For example, a producer could sell a Carmel Valley Caves, Central Coast, Chardonnay, on a wine produced from grapes grown wholly outside of the Carmel Valley AVA. The production of such a brand could potentially dwarf the production of the entire Carmel Valley AVA. ${ }^{162}$

Similarly, semi-generic wine types may also be labeled with geographic references that do not indicate the origin of the wine in the bottle. ATF explicitly recognizes hundreds of foreign appellations of origin, and prohibits their use on wine labels in the United States unless they state the true foreign origin of the wine, ${ }^{163}$ however, the sixteen semigeneric terms may appear on a wine of any origin provided that its true origin is noted on the label. ${ }^{164}$ By designating these terms semi-generic, ATF acknowledges that they have some geographic significance and are not completely generic. Use of these semi-generic terms on American wines, such as California Champagne or California Chianti, does not indicate the origin of the wines and thus is not in conformity with ATF's

160. To complicate the matter further, ATF also made no provisions for the potential postgrandfathering date creation of an identically named brand name and AVA. For example, if a brand Rutherford Vista Winery had been created in 1987 in Kentucky, then when the Rutherford AVA was created in 1990 in California, under 27 C.F.R. $\$ 4.39$, the winery in Kentucky would be required to produce its wines from grapes sourced in the Rutherford AVA in Califomia. In 1992, ATF issued a notice of proposed rulemaking that would remedy this issue, which it described as a "regulatory oversight," by setting a rolling grandfathering date. This proposed rolling grandfathering date would have allowed any geographic brand name used prior to the creation of a similarly named AVA to continue to be used subject to the same conditions as those used prior to 1986. See Wine Labeling Amendments, 57 Fed. Reg. 27,401 (proposed June 19, 1992). ATF did not adopt a rolling grandfathering date in its subsequent Final Rule that addressed the issues raised in its 1992 Notice of proposed ruleunaking. Wine Labeling Amendments, 59 Fed. Reg. 14,551, 14,552 (Mar. 29, 1994).

161. Any such sale would have to be accompanied by existing inventory or other brand assets so as not to violate trademark law's prohibition on assignments in gross.

162. See id. The Carnel Valley AVA consists of approximately 19,200 acres. See Establishment of Carmel Valley Viticultural Area, 47 Fed. Reg. 55,915 (Dec. 14, 1982).

163. 27 C.F.R. $\$ 12(2000)$ lists "examples" of foreign nongeneric names of geographic significance. 27 C.F.R. $\$ 4.24$ (c) $(2000)$ prohibits their use on wines of any origin other than that indicated by the name.

164. 27 C.F.R. $\$ 4.24($ b) (2000). See supra notes $115-119$ and accompanying text. 
general plan that geographic terms should indicate the region in which the wine was grown.

Other inaccurate uses of geographic terms in the United States can be found in grape variety names and "type designations of varietal significance." These include Johannisberg Riesling, Napa Gamay, Gamay Beaujolais, Pinot Saint George, and Muscat Frontignan. ${ }^{165}$ These terms do not indicate the origin of the wine; a California Gamay Beaujolais does not come from anywhere near Beaujolais, France. As will be described in Part $\mathrm{IV}$, these terms have been the subject of recent rulemaking that resulted in a scheduled phaseout of this type of nonconforming use of geographic terms on American wines.

Finally, geographic bottling trade names may also indicate a geographic origin other than the true origin of the grapes. For example, a hypothetical "Big Ranch Winery California Zinfandel, Produced and Bottled by Monterey Caves, Monterey, California" need not be grown in the Monterey AVA or in Monterey County, California. Bottling trade names thus illustrate another nonconformity with the wine-labeling scheme's general plan that geographic terms should appear on wine labels in order to indicate the region in which a wine was grown.

\section{Consequences of Nonconforming Uses of Geographic Terms}

Nonconformity in the use of geographic terms on wine labels undermines the purposes of ATF's comprehensive labeling scheme by causing two primary injuries: (1) consumer confusion and (2) dilution of goodwill that has become associated with those place names through historical promotion of regional names by producers.

\section{Consumer Confusion}

Nonconforming uses of geographic place names confuse the consumer. Many wine consumers are already intimidated by wine labels, and even the most sophisticated consumers might sometimes need to consult a reference book to decipher a foreign wine label. An American wine label ought not be equally confusing. ATF's wine-labeling regnlations exist ultimately as an expression of congressional intent that American consumers ought not be misled by American wine labels. Wine consumers make purchase decisions based on a multitude of factors, ${ }^{166}$ but with respect to any given class of wine (for example, still, sparkling, fortified), there are three primary product identifiers: brand, origin, and grape variety or wine type. ${ }^{167}$ The brand name is typically the most prominent feature on an

165. See 27 C.F.R. $\$ \$ 4.28,4.92(2000)$.

166. For a comprehensive analysis of the wine-consumer and the wine-marketing mix, see ToNY SPAWton, Marketing PlanNing For Wine (1990).

167. Moulton \& Spawton describe the elements of product differentiation in the wine market: 
American wine label and thus is the written feature on the label that most readily conveys information to the consumer. ${ }^{168}$ When a geographic term appears in a brand name, it is natural for the consumer to assume that the product originated in that region. This is particularly true in the case of wines, given the importance of geographic location to grape growing and, consequently, to wine production. For example, upon discovermg a hypothetical Chateau Paso Robles, central Coast, Syrah, a consumer might think that the wine originated in the Paso Robles AVA ${ }^{169}$ rather than the Central Coast AVA. ${ }^{170}$

When several nonconforming geographic terms appear on a single wine label, the opportunities for confusion multiply. For example, the following hypothetical label would be legal under ATF regulations, assuming its brand name was grandfathered: Oakville Crest Columbia Valley Gamay Beaujolais, Produced and Bottled by Willamette Valley Bottlers, Sonoma, California. It is doubtful that a consumer not familiar with Title 27 of the Code of Federal Regulations would know whether this wine was made froin grapes grown in the Oakville $\mathrm{AVA}^{171}$ in California, the Columbia Valley AVA ${ }^{172}$ in Washington, the Beaujolais region of France, the Willamette Valley AVA $^{173}$ in Oregon, or Sonoma, California.

The Wine Institute, in its White Paper on Geographic Brand Names, acknowledged the belief held by many of its members that "the use of geographic brand names can potentially result in overuse, confusion, and consumer deception.... At times, geographic eleinents can appear on a wine label many times, even though the appellation of origin is not what is implied by the use of geographic terms." $" 174$ The California legislature has

Product differentiation is a key marketing strategy designed to insulate a product from direct competition. It is commonly used to differentiate wines according to their type, e.g. sparkling, still, fortified; their place of origin, e.g. vineyard, community, county or province, region, state or country; the variety of grapes used for the wine, e.g. chardonnay, cabernet sauvignon; and brand or marque, e.g. Partager, Bolla, Penfolds, Gallo. Variations may be used to indicate proprietary blends, such as "Meritage" or "Insignia" or to suggest quality, such as "Vintners Reserve["], "Estate Bottled", or a government certification. These different indicators are often used together, and the relative weight given to each (as indicated by the prominence of the label or in promotion) is determined by consumer preferences and perceptions, the price class of the wine, and the market being served.

Supra note 21, at 8-9.

168. ATF has acknowledged this fact and noted that geographic brand names can be mislcading:

ATF believes that the brand name, usually the most prominent item on a wine label, in certain instances conveys information to the consumer. In the case of a geographic brand name of viticultural significance, ATF believes that such a name on a label indicates the origin of the wine, that is, the place where the grapes were grown.

Wine Labeling and Advertising; Use of Geographic Brand Names, 51 Fed. Reg. 20,480, 20,481 (June $5,1986)$.

169. 27 C.F.R. $\$ 9.84$ (2000).

170. 27 C.F.R. $\$ 9.75(2000)$.

171. 27 C.F.R. $\$ 9.134(2000)$.

172. 27 C.F.R. $\$ 9.74(2000)$.

173. 27 C.F.R. $\$ 9.90(2000)$.

174. WHITE PAPER, supra note 127 , at 2. 
also expressed its belief that nonconforming uses confuse the consumer: "[C]ertam producers are using Napa appellations on labels, on packaging materials, and in advertising for wines that are not made from grapes grown in Napa County, and... consumers are confused and deceived by these practices." ${ }^{" 175}$ Consumer survey data support this assertion. ${ }^{176}$ Nonetheless, ATF's regulations permit such multiple geographic terms on a single wine label, relying on the premise that the appearance of a true appellation of origin on the label will offset any potential consumer confusion.

Given that the purpose of ATF's labeling authority is "to insure that the purchaser should get what he thought he was getting," 177 this multitude of nonconforming uses of geographic terms on wine labels, and the inevitable consumer confusion that results, undermines the integrity of ATF's consumer protection regulations. The current regulatory scheme, rife with nonconformity, cannot achieve its goal of minimizing consumer confusion. On the contrary, allowing continued nonconforming uses of geographic terms only serves to perpetuate consumer confusion.

\section{Dilution of Goodwill Associated with Famous Place Names}

Even in the absence of consumer confusion, nonconforming uses can undermine the purpose of ATF's appellation of origin labeling scheine, which is to ensure that regional identifiers are used consistently. ${ }^{178}$ As wine regions have developed, American wine producers have begun promoting their wines based on regional identity. ${ }^{179}$ Many regions have become wellknown to wine consumers, who often seek out products from particular origins. Even when consumers know that certain wines are not from the regions identified on their labels, such labeling practices can make it more

175. CAL. Bus. \& Prof. Code § 25241(a)(2) (West Supp. 2001).

176. Field Research Corporation, a San Francisco-based research firm specializing in marketing and public opinion surveys, conducted a double-blind survey of 981 potential purchasers of red and white varietal wines to determine whether potential purchasers of such wines are likely to believe that wines that include the word "Napa" in their brand name are made from grapes grown in Napa County, Napa Valley, or the Napa area even when the bottle labels do not so indicate or provide another appellation. The survey found that $52 \%$ of survey respondents shown the Napa Ridge brand (Lodi and North Coast appellation) wines associated the geographic origin of the wine with Napa, as compared to only $15 \%$ for the non-Napa Ridge brand wines (Sable Ridge and Tuming Leaf brands), a difference of $37 \%$. Further, $42 \%$ of survey respondents shown the Napa Ridge wines explicitly indicated their belief that the grapes for the wine were grown in Napa County or Napa Valley. The comparable percentage for the non-Napa brand wines was $14 \%$, a difference of $28 \%$. See Declaration of E. Deborah Jay, Bronco Wine Co., supra note 2.

177. H.R. REP. No. 74-1542, supra note 40, at 10.

178. See discussion supra Parts Il.A-B.

179. See, e.g., Abby Sawyer \& Jim Hammett, American Appellations Earn Distinction as Marketing Tool, WINE Business MONTHLY, June 1998, at I. See also Fletcher, supra note 21; Heald \& Heald, supra note 21. 
difficult to distinguish those wines that are accurately labeled with regional identifiers. In trademark law, this injury is known as "dilution." "180

The Lanham Act creates a federal cause of action to protect famous trademarks froin unauthorized users that attempt to trade upon the goodwill and established renown of such marks and, in so doing, dilute their distinctive quality. ${ }^{181}$ To determine whether a mark is famous for trademark purposes, a court may consider multiple factors, including:

the duration and extent of use of the mark in connection with the goods and services with which the mark is used; ... the duration and extent of advertising and publicity of the mark; ... [and] the degree of recognition of the mark in the trading areas and channels of trade used by the marks' [sic] owner .... ${ }^{182}$

These factors are similar to those that ATF examines (substituting "geographic place name" for the word "mark") when a new AVA is proposed. In making a determination on a new viticultural area, ATF must take into account "[e]vidence that the name of the viticultural area is locally and/or nationally known as referring to the area specified in the application...."183 Thus, an approved AVA necessarily has made some showing of fame and can be considered, for analytical purposes, analogous to a famous mark. However, ATF allows nonconforming uses of famous geographic place names; uses that dilute their distinctive qualities.

The regional renown associated with wine regions, defined using these criteria, would likely outweigh the fame of most geographic brand names. A consumer thus is likely to associate a geographic term in a brand name with the wine-producing region of the same or similar name rather than with the producer of the brand. For example, a consumer is more likely to associate a wine displaying the Napa Ridge brand name with the Napa Valley than with the company that owns the Napa Ridge mark. ${ }^{184}$ Consequently, the "goods/place association"185 of many geographic brand names with wine may be more an association with the wine region indicated by the brand than an association with the producer of the wine brand itself. For this reason, the users of such brand names can be considered to be trading on the goodwill and renown of the better-known geographic place names.

For years, producers have collectively and individually built up the goodwill associated with their regions through promotional literature,

180. Federal Trademark Dilution Act of $1995 \S 3,15$ U.S.C. $\$ 1125$ (c) (1994).

181. Id.

182. Id.

183. 27 C.F.R. $\$ 4.25 \mathrm{a}(\mathrm{e})(2)(\mathrm{i})(2000)$. See supra note 91 and accompanying text.

184. Consumers undoubtedly associate the terms Napa Valley and Sonoma Valley, for example, with wine. See, e.g., Benjamin \& Podolny, supra note 30, at 563 (describing Napa Valley and Sonoma Valley as "high-status regions").

185. See, e.g., In re Nantucket, 677 F.2d 95, 99 (C.C.P.A. 1982). 
advertisements, and tourism. ${ }^{186}$ This goodwill is unquestionably valuable. ${ }^{187}$ Empirical studies have shown that consumers are willing to pay more for wines originating from regions well-known for the quality of their wines. ${ }^{188}$ The existence of wines on the market that prominently display famous place names on their labels, when the wines therein are not sourced from those regions, dilutes the value of famous place names, even if the consumer is not confused by the label because of an offsetting true indication of origin. In its recent White Paper on Geographic Brand Names, the Wine Institute states: "The misuse of geographic brand names can arguably have serious impact on the integrity and reputation of an appellation. It is the 'dilution' of the appellation that is of concern."189

The potentially unlimited production of wines labeled with nonconforming geographic terms increase the potential dilutive effect of these nonconforming uses on the goodwill, renown, and distinctive qualities associated with appellations of origin.

\section{IV \\ Elimination of NonCONFORMING USES OF GEOgraphic REFERENCES ON AMERICAN WINE LABELS}

The debate over geographical indications on American wine labels has produced several reform proposals. The following Section' details the most prominent of these existing proposals. Some aspects of the existing reform proposals would likely prove beneficial in reducing consumer confusion and regional name dilution, but none of the existing proposals alone would adequately address the current need for reform. This Comment thus

186. As recently as October 2000, ATF stated in a published rulemaking decision: "ATF believes that consumers have learned to attach significance to ... appellations of origin . . . on grape wines. This belief is based on the fact that for many years the grape wine industry has heavily utilized . . . appellations of origin . . . in the marketing of grape wines." See Labeling of Flavored Wine Products, 65 Fed. Reg. 59,718, 59,720-21 (Oct. 6, 2000); see also CAL. Bus. \& Prof. Code $\$ 25241(a)(1)$ (West Supp. 2001). The regulations state:

The Legislature finds and declares that for more than a century, Napa Valley and Napa County have been widely recognized for producing grapes and wine of the highest quality. Both consumers and the wine industry understand the name Napa County and the viticultural area appellations of origin contained within Napa County (collectively "Napa appellations") as denoting that the wine was created with the distinctive grapes grown in Napa County.

187. The Globe in a Glass, Economisr, Dec. 18, 1999, at 98 ("In California, growers in the Napa Valley know that their region's name is worth a huge mark-up on the bottle price ....").

188. See, e.g., Stuart Landon \& C.E. Smith. The Use of Quality and Reputation Indicators by Consumers: The Case of Bordeaux Wine, 20 J. CONSumer POL'y 289 (1997); GúnTER Schamel, Individual and Collective Reputation Indicators of Wine Quality (Univ. of Adelaide, Centre for Int'l Econ. Studies, Policy Discussion Paper No. 0009, 2000), available at HTTP://Www.ADELAIDE.EDU.Au/CIES/0009.PDF; Günter Schamel \& Kym Anderson, Wine Quality and Regional Reputation: Hedonic Prices for Australia and New Zealand (Univ. of Adelaide, Centre for Int'l Econ. Studies, Policy Discussion Paper No. 0103, 2001), available at http://www.adelaide.edu.au/CIES/0103.pdf.

189. WHITE PAPER, supra note 127, at Executive Summary 2. 
proposes that ATF adopt a comprehensive reform package that borrows from the most promising aspects of the existing reform proposals, while incorporating into labeling reform a solution commonly applied to nonconforming use in the zoning context: a phaseout of nonconforming uses over a reasonable ainortization period.

\section{A. Existing Reform Alternatives and Their Shortcomings}

\section{Disclaimers and Signals}

The ATF currently follows a policy of requiring disclaimers. The requirement that a true appellation appear on the label of a grandfathered brand name and on the label of a semi-generic type wine disclaims the false origin indicated by such brand names and wine types. This disclaimer, given labeling regulations that allow the appellation to appear inconspicuously on a label, is insufficient.

Disclaimers purport to address consumer confusion. However, even supposing that the appearance of two indications of origin on a single label did dispel confusion over origin caused by the prominent geographic brand name or wine type designation (a faulty premise, as discussed in Part III.C), disclaimers do not address the nonconfusion problem of dilution. Furthermore, disclaimers are only effective in preventing confusion if used in a highly conspicuous manner. Thus, another drawback to this type of solution is that there would be more clutter on wine labels. And one should never underestimate the creative abilities of label designers to find nerv ways to make a false geographic reference more prominent than a disclaimer.

Requiring signals on wine labels to highlight which term on the label refers to the origin of a wine is another reform alternative. ATF could require a wine's appellation of origin to be followed or preceded by the signal "AVA" or "Appellation." This might reduce consumer confusion and lead to consumers becoming more aware of the geographic origin of wines in general, but it might also spawn more consumer confusion if consumers do not know the meaning of the terms "Appellation" or "AVA." Signals, like disclaimers, would not address the issue of dilution.

\section{Rolling Grandfathering Date}

United Distillers and Vintners petitioned ATF in 1997 to remove the 1986 grandfatherimg date and replace it with a rolling grandfathering date. ${ }^{190}$ This proposal would permit continued sales of wines using nonconforming geographic brand names if the brand name had been approved for

190. ATF made an identical proposal in 1984. See supra note 160. In deciding against this reform in 1986, ATF stated that it had decided to include this issue "in a forthcoming major project to review and revise all of the FAA Act labeling and advertising regulations." Wine Labeling Amendinents, 59 Fed. Reg. 14,551, 14,552 (Mar. 29, 1994). This forthcoming major reform project is long overdue. 
use prior to the creation of a viticultural area with the same or similar name. ${ }^{191}$ To date, ATF has not issued a notice of proposed rulemaking on this petition. The rationale behind this idea is that a producer with a geographic brand name approved after July 7, 1986, should not be penalized for any viticultural area established after the geographic brand name. However, this proposal would only exacerbate the existing confusion and dilution problems because it would vastly increase the number of grandfathered brand names. In sum, this proposal only addresses the issue of priority in brand versus appellation. It does not address the more fundamental issue of consumer confusion that manifests itself regardless of whether the viticultural area or the trademark came first.

\section{First in Time, First in Right}

Article 24.5 of the TRIPs Agreement provides that if a trademark using a geographical indication is properly registered, applied for, or acquired in good faith before that geographical indication is protected in its country of origin, the mark's registration or eligibility for registration shall not be prejudiced by any measures adopted by any member state to implement the Agreement. ${ }^{192}$ Some in the industry argue that this provision means that existence of a trademark should trump creation of an identically named viticultural area. ${ }^{193}$ ATF, as discussed in Part II.B.3, does not subscribe to this view.

The argument that any use of a trademark should absolutely bar the future creation of an identically named viticultural area is problematic because a trademark holder can never prevent fair use by others to describe the geographic origin of their products. Accurate use of an AVA represents fair use of a geographic term to indicate product origin. Furthermore, such an interpretation is impractical; under this reading, few of the presently existing AVAs could have been created with their names as approved.

\section{Prohibiting the Expansion of Geographic Brand Names}

Some in the industry have proposed prohibiting expansion of geographic brand names by restricting volume and labeling practices to historical brand usage. Such a policy, if applied retroactively, might help to limit much of the current confusion and dilution threats. Even if applied

191. See WHITE PAPER, supra note 127, at 22 .

192. TRIPs Agreement, supra note 18, art. 24.5.

193. See WHITE PAPER, supra note 127, at 35. This reading is difficult to square with Articles 22 and 23 of the TRIPs Agreement, which provide broad protections for geographical indications, subject to the exceptions of Article 24. Article 23.2 of the Agreement provides:

The registration of a trademark for wines which contains or consists of a geographical indication identifying wines... shall be refused or invalidated, ex officio if domestic legislation so permits or at the request of an interested party, with respect to such wines or spirits not having this origin.

TRIPs Agreement, supra note 18, art. 23.2. 
retroactively, however, the grandfathering loophole could still cause significant consumer confusion and dilution of regional names. If expansion were prohibited based on historical brand usage up until the adoption of such a policy, it would only serve to maintain the status quo. The status quo is not an acceptable alternative solution. A prohibition on expansion of use of geographic brand names on its own is insufficient, although such a policy should be part of a comprehensive plan to remove nonconforming uses from the marketplace.

\section{Individual State Efforts}

States may adopt wine-labeling laws that are stricter than those of ATF. In such a case, the stricter law trumps the federal law. Oregon, for exainple, has adopted "rigorous" labeling standards, ${ }^{194}$ and prohibits the use of any geographic term on a wine label unless that wine meets the appellation of origin requirements for the area indicated. ${ }^{195}$ Oregon further prohibits the use on wine labels of semi-generic terms and grape variety names of geographic significance, ${ }^{196}$ and requires $100 \%$ grape source to qualify for an Oregon appellation of origin. ${ }^{197}$ Oregon's wine industry is thriving under these regulations. ${ }^{198}$

The legislation passed by California, ${ }^{199}$ which produces over $70 \%$ of all wine sold in the United States, ${ }^{200}$ was a necessary emergency step to protect the goodwill of Napa County and its over 250 wineries from the very real threat of marketplace dilution and consumer confusion. If upheld, it would help eliminate confusion with respect to the names of the viticultural areas found wholly within Napa County, but it would only do so for wines produced or sold in California, and it will not resolve the larger problein of nonconforming uses in geographic brand names. Many other geographic place names are used in a confusing and dilutive manner.

California's legislative act, however necessary, and Oregon's efforts, however effective locally, do not provide the comprehensive national reform that is necessary to eradicate consumer confusion and regional name dilution. ${ }^{201}$ Moreover, many wine producers have indicated that they

194. OR. ADMIN. R. 845-10-910(1) (1999).

195. OR. ADMIN. R. 845-10-920(4)(f) (1999). Oregon does allow brand names used prior to 1977 (of which there are very few) to continue to be used in a nonconforming manner. See id.

196. OR. ADMIN. R. 845-10-915 (1999).

197. OR. ADMIN. R. 845-10-920 (1999).

198. See, e.g., Frank J. Prial, Oregon Steps out of California's Shadow, N.Y. Tmes, Aug. 9, 2001, at F2.

199. CAL. Bus. \& Prof. Code $\$ 25241$ (West Supp. 2001). See discussion supra Part II.C.3.

200. See Key Facts: California Wine Industry Statistical Highlights, supra note 61.

201. Such efforts are also open to challenges on the grounds that ATF's federal wine-labeling scheme pre-empts state laws that might conflict with the federal scheme. The Twenty-First Amendment's grant of power to states to regulate alcoholic beverages might complicate such preemption arguments. 
will only support a federal solution, given ATF's power to regulate all wine sold in interstate commerce.

\section{B. A Comprehensive Reform Proposal}

Since current reform efforts to address the problems created by nonconforming uses are inadequate, this Section outlines a new and comprehensive proposal for eliminating nonconforming uses of geographic terms on wine labels. This new proposal serves the purposes of both ATF's winelabeling scheme and of trademark law, and draws on zoning law as a model for how nonconforming uses can be terminated fairly.

Courts and zoning authorities have adopted policies that strictly construe against exceptions permitting nonconforming uses, and impose numerous restrictions on their continued use. ${ }^{202}$ Such restrictions include limitations with respect to the extension, enlargement, alteration, change in ownership, and discontinuance of nonconforming uses. ${ }^{203}$ In rare cases, such as where a nonconforming use causes a public nuisance, a zoning authority may effect the immediate termination of a nonconforming use. ${ }^{204}$ More typically, a zoning authority seeking to eliminate nonconforming uses will adopt the constitutionally valid policy of requiring gradual removal of nonconforming uses without compensation following a reasonable amortization period. ${ }^{205}$ In eliminating nonconforming uses, the courts have subordinated the rights of owners of nonconforming uses to the goal of the comprehensive zoning scheme to improve the general public welfare. $^{206}$

A regulatory "zoning" scheme, such as ATF's, that allows for the unlimited expansion of nonconforming uses, the potentially perpetual enjoyment of nonconforming uses, and the potential revival of long-dormant nonconforming uses, is inconsistent with the very purpose of zoning. ATF's wine-labeling scheme would better serve its core purposes, as well as those of trademark law, were it to apply lessons learned from inunicipal zoning to its wine-labeling scheme. The following Sections propose amendments to ATF's wine-labeling scheme that seek to eliminate nonconforming uses of geographic terms on American wine labels.

\section{Phaseout with Reasonable Amortization Period}

The possibility of phasing out a nonconforming use is not new to ATF. ATF has already adopted a plan to eliminate the use of "incorrect"

202. 66 CAL. JuR. 3D Zoning and Other Land Controls $\S 120$ (1981).

203. Id.

204. Id.

205. See Matthew Bender \& Co., Zoning and Land Use Controls $\$ 41.04$ (2001).

206. See, e.g., Heagan v. Borough of Allendale, 127 A.2d 181, 190 (N.J. 1956) (explaining that the policy of law with respect to nonconforming uses is to subordinate individual interests of nonconforming users to interests of the community in preserving its zoning plan). 
grape variety names over a reasonable amortization period. ${ }^{207}$ Most of the grape variety names described as "incorrect" by ATF incorporated a geographic place name in the varietal name (such as Gamay Beaujolais, Johannisberg Riesling, and Napa Gamay). ${ }^{208}$ In reaching its decision on Johannisberg Riesling, ATF stated that such grape variety names should be phased out "so as to ensure that consumers are not misled, but instead are adequately informed as to the identity of the wine. $\$ 209$ In its decision to phase out the use of Gamay Beaujolais, ATF stated that it has long been its goal to "eliminate the use of incorrect grape variety names in the labeling of American wines, even where those names have been used on a longstanding basis in the United States."210

This Comment endorses an analogous phaseout of the nonconforming uses of all geographic terms on wine labels, even where those names have been used on a longstanding basis in the United States. A regulatory scheme designed to ensure consistency and accuracy in the use of geographic references on wine labels logically should begin by recognizing the most famous wine appellations of the world. Accordingly, the United States ought to follow the lead of other inajor wine-producing nations and work with the European Union to devise a plan to phase out the use of semi-generic terms on American wine labels. ${ }^{211}$

The experience of Australia demonstrates that a phaseout of these terms is feasible in the United States and that ten years should provide a reasonable period of time to achieve a phaseout. ${ }^{212}$ Australia is a wine market that had similarly entrenched use of European place names such as

207. See 27 C.F.R. $\S \S 4.28,4.92$ (2000). The rulemaking history of the Johannisberg Riesling and Gamay Beaujolais rules can be traced through the following: Gamay Beaujolais Wine Designation, 59 Fed. Reg. 15,878 (proposed Apr. 5, 1994); Gamay Beaujolais Wine Designation, 62 Fed. Reg. 16,479 (Apr. 7, 1997); Gamay Beaujolais Wine Designation, Correction, 62 Fed. Reg. 33,746 (June 23, 1997); Petition for Johannisberg Riesling; Proposed Addition of Grape Variety Names for American Wines; Request for Additional Information for Other Proposed Grape Varieties, 64 Fed. Reg. 813 (proposed Jan. 6, 1999); Johannisberg Riesling; Deferral of Compliance Date, 64 Fed. Reg. 753 (June 6, 1999); Extension for Johannisberg Riesling, Additional Grape Varieties, 64 Fed. Reg. 49,385, 49,387 (Sept. 13, 1999).

208. 27 C.F.R. $\$ \S 4.28,4.92$.

209. Extension for Johannisberg Riesling, Additional Grape Varieties, 64 Fed. Reg. at 49,387.

210. Gamay Beaujolais Wine Designation, 62 Fed. Reg. at 16,484.

211. Wine and wine labeling in Europe are subject to European common market agricultural regulations. Each member of the European Union reciprocally recognizes each other member's regional designations of origin. The European Union has successfully negotiated agreements with several major wine producers to phase out use on wines not originating in the areas indicated by those terms deemed semi-generic by ATF. See, e.g., Agreement Between the European Community and Australia on Trade in Wine-Protocol-Exchange of Letters, Mar. 31, 1994, 1994 O.J. (L 086) 3.

212. This phaseout would require congressional action as well as ATF rulemaking. In 1997, a large wine producer successfully lobbied Congress to add a rider to the Taxpayer Relief Act of 1997 that accorded official recognition to the list of semi-generic terms. The producer sought protection against the potential of ATF independently eliminating the use of semi-generic terms. See Taxpayer Relief Act of $1997 \$ 910$, codified at 26 U.S.C. $\$ 5388$ (1994 \& Supp. V 2000) (listing in the code the semi-generic terms as "certain names treated as semi-generics"). 
Champagne and Chablis on its domestically produced wines. In 1994, Australia signed an accord with the European Union, pledging to phase out use of European place names in exchange for reciprocal recognition of Australian place names within the European Union. ${ }^{213}$ A few of the semigeneric terms would be more difficult to phase out than the others, but most of them were unnecessary and can be replaced by truly generic descriptors. ${ }^{214}$ Furthermore, usurpation of several of the most famous foreign place names commonly associated with wine seriously undermines the credibility of American producers seeking to establish regional reputations for their own viticultural areas. ${ }^{215}$ ATF thus should implement a phaseout of semigeneric terms over a ten-year period.

Similarly, within ten years, ATF should require that all wines labeled with geographic brand names and geographic bottling trade names qualify for, and state on their label, either (1) the appellation of origin to which that brand or bottling trade name refers; or (2) the appellation of origin of the county or counties in which the appellation indicated by the geographic brand name is located. Within twenty years, ATF should require that all wines labeled with geographic brand names and geographic bottling trade names qualify for, and state on their label, the appellation of origin to which that brand or bottling trade name refers. When ATF adopted its wine-labeling scheme in 1978 , it "determined that no vineyards will be 'grandfathered' into an area merely because they presently supply, or were planted to supply, grapes currently using a particular viticultural area description." 116 This was done "to establish rational and uniform viticultural area boundaries ...."217 ATF did not apply this same logic to geographic brand names in 1986, nor did it set rational or uniform limits on their use. Instead, it gandfathered brand names merely because they were presently in use. ATF should now establish rational and uniform

213. See Agreement Between the European Community and Australia on Trade in Wine, supra note 211 .

214. Champagne, for example, could be replaced easily by "Sparkling Wine"; Burgundy by a varietal name or a generic descriptor such as "Valley Red" or "California Red." Other terms, such as Port and Sherry might be more difficult, though not impossible, to replace, for several reasons. For a more thorough discussion of some of the practical difficulties in phasing out certain terms, see Richard Mendelson \& Michael Maher, Will This Ship Ever Leave Port?, Practical Wingry \& VinEYard, July 1999 , at 66 .

215. It is unlikely that American producers would look kindly upon a ltalian-grown "Sonoma Valley" Chardonnay or a French-grown "Willamette Valley" Pinot Noir. Napa is famous for its Cabernet Sauvignon, and producers in other parts of the world might imitate the style of a Napa Valley Cabernet. Nonetheless, a wine made in Spain, for example, in a similar style to a Napa Cabernet could not be sold in Europe or the United States as a Spanish Napa. Oregon wine-labeling law, whose express purpose is to "[e]nsure accurate presentation of the product" and "[e]ncourage Oregon's wine industry by enhancing the quality, image and marketability of Oregon wine," forbids the use of ATF's semigeneric terms on Oregon wine labels. OR. ADMIN. R. 845-10-910, 845-10-930 (1999).

216. Labeling and Advertising of Wine: Appellation of Origin, Grape-Type Designations, Etc., 43 Fed. Reg. 37,672, 37,673 (Aug. 23, 1978).

217. Id. 
boundaries on the use of geographic brand names by phasing out grandfathered geographic brand names.

The phaseout here proposed would provide brand owners with reasonable latitude in grape sourcing in and around the geographic area referenced by the brand or bottling trade name during the initial phaseout period. By limiting the use of a brand name to a single county, it would set reasonable limits on potential production volumes during this initial period. It would provide an additional reasonable period of time, as well as strong incentives, for producers to discontinue any misleading labeling practices and to develop new nongeographic brands if necessary.

\section{One Hundred Percent Grape Origin Requirements}

Under the current ATF regulations, $15 \%$ of the wine in each bottle labeled with an AVA can derive froin grapes grown outside the viticultural area for which the wine qualifies. ${ }^{218}$ This $15 \%$ equates to one glass in each bottle of wine that inay derive from a source other than the wine's stated origin. This literal liquid dilution of wine potentially deceives consumers who inight expect that all of a wine labeled with an AVA originates in that AVA. ${ }^{219}$ This liquid dilution also can contribute to place name dilution, as the potential production of a region is increased by the $15 \%$ of nonregional wine allowed in each bottle. It also potentially favors those wine producers capable of simultaneously sourcing wine from both a high value-added, high grape-cost AVA and a low-cost region. Such a producer could lower its overall costs while maintaining a bottle price consistent with those obtained by wines carrying the high value-added AVA name. Finally, this liquid dilution contradicts ATF's requirement that an AVA applicant provide evidence of common viticultural characteristics within a region that distinguish it from surrounding areas. ${ }^{220}$ The $15 \%$ of each bottle labeled with an AVA that may originate from outside that AVA potentially masks any regional wine characteristics that might emerge from wine regions with distinguishable grape-growing environments. At the end of the initial tenyear phaseout of nonconforming uses of geographic terms, ATF should require that $100 \%$ of the wine in a bottle originate from grapes grown in the geographic area indicated on the bottle. If $100 \%$ of the wine comes from the region indicated on the label, there can be no consnmer confusion or place name dilution.

\section{Trademark Priority Provision}

To minimize potential future nonconformities, ATF should address the issue of prior rights to geographic names. ATF should amend its

218. See supra note 69 and accompanying text.

219. See supra note 79 and accompanying text.

220. See supra note 91 and accompanying text. 
criteria for the establishment of AVAs. ${ }^{221}$ ATF should prohibit the establishment of any AVA for which the name either (1) is part of a continuously used federal trademark registration for wine and was registered at least five years before the filing of the AVA petition, or (2) has been used continuously in a brand name for wine under approved labels for at least five years prior to the filing of the petition to establish the AVA. To protect against a potential rush to trademark geographic place names, ATF should make exceptions where the petitioner can establish that the AVA name had viticultural significance prior to the first use of the name on wine labels by the current brand or trademark owner or his predecessor(s) in interest. In making this determination, ATF should weigh the fame of a brand name against the pre-existing fame of a proposed viticultural area. Where establishment of an AVA is found to be appropriate, ATF should allow a geographic brand name holder's continued use of a brand but prohibit any significant increase in production volumes. Such a limitation would discourage continued use of such a brand name and would serve to minimize any dilutive effect such brand name would have on the goodwill associated with the regional name.

\section{Identical Surname Exception}

ATF should provide one narrow exception to the phaseout of nonconforming uses. A geographic brand name or geographic bottling trade name that is also the surname of a winery owner or one of its predecessors in interest should be allowed to be used in association with wines bearing an appellation of origin other than that referred to by the surname. This exception should apply if the surname is registered as a federal trademark for wine or used as a brand name for wine prior to the establishment of the appellation of origin and continuously thereafter. The need for such an exception would be rare, as few of the approved AVA names are also potentially surnames.

\section{Disclaimer, Typeface, and Label Placement Requirements}

During the phaseout periods, as an incentive for producers to arrive at conformity as quickly as possible, ATF should require all nonconforming uses to be labeled with a conspicuous disclaimer of a minimum font size, appearing on the same label as the brand name and type designation, stating: "[Geographic brand or bottling trade name or semi-generic name] does not indicate the origin of the grapes in this wine." To prevent deceptive use of winery addresses, ${ }^{222}$ ATF should require that this mandatory

221. 27 C.F.R. $\$ 4.25 a(e)(2)(2000)$.

222. For a good example of this, look for a bottle of Forest Glen brand wines. See Forest Glen, at $\mathrm{http}: / / \mathrm{www}$. forestglenwinery.com/ (last visited Oct. 2, 2001). These wines, labeled with the California appellation, are not derived from grapes grown in Sonoma, yet the term Sonoma County appears on a 
label information ${ }^{223}$ appear in typeface no larger than two millimeters in height and on the same label as the government health warning. This typeface requirement should also be applied to wine advertising and promotional materials. ${ }^{224}$

If implemented collectively, this series of reforms would lend credibility to ATF's wine-labeling scheme. These proposals would minimize deceptive labeling practices and the resulting consumer confusion and regional name dilution. As the next Section discusses, there are no constitutional roadblocks to the implementation of such reforms.

\section{Constitutionality of the Proposal to Phase Out Nonconforming Uses of Geographic References}

The proposal outlined above would need to be implemented through proper administrative rulemaking. Assuming that ATF satisfied the requirements of procedural due process through proper notice and cominent procedures, the substance of the proposal outlined above still would need to pass constitutional muster. The following Sections examine the two constitutional objections most likely to be raised against enactment of such a scheme to phase out nonconforming uses: (1) regulatory takings and (2) cominercial free speech.

\section{Regulatory Takings}

Government regulation can constitute a "taking" of property when the regulation "goes too far."225 There is no precise formula or rule for determining when a regulation constitutes a taking, but the Supreme Court has outlined three factors of "particular significance": "(1) the economic impact of the regulation on the claimant; (2) the extent to which the regulation has interfered with mvestment-backed expectations; and (3) the character of the governmental action."226 In applying these factors, the Court generally will find a taking if the regulation denies all economically viable use of a property, and does so in such a way as to interfere with reasonable expectations for use. ${ }^{227}$ Of course, before there can be a taking of property, there must exist a property right.

medallion-shaped label. The brand Forest Glen is owned by Bronco Wine Company. See U.S. Patent and Trademark Office, Trademark Registration, Serial No. 75,261,176 (filed Sept. 18, 2000), available at http:/tess.uspto.gov/. The Sonoma County Grape Growers Association filed a complaint with ATF concerning this labeling practice. See Forest Glen Complaint Filed, WiNE BuSINESS INSIDER, April 19, 1997 , at 2 .

223. See 27 C.F.R. $\$ 4.35$ (2000).

224. ATF regulates advertising materials. See 27 C.F.R. $\$ \S 4.60-65$ (2000).

225. Pennsylvania Coal Co. v. Mahon, 260 U.S. 393, 413 (1922).

226. Connolly v. Pension Benefit Guaranty Corp., 475 U.S. 211, 225 (1986) (internal quotations omitted) (citation omitted).

227. Compare Penn Cent. Trans. Co. v. New York, 438 U.S. 104, 136-38 (1978) (no taking when regulation did not deny owners all profitable use of a building), with Lucas v. South Carolina Coastal 
The property right at issue under a potential takings claim here is the right to use a geographic brand name or trademark. The rights conferred to registered owners of trademarks and to those with approved wine brands are limited property rights. Trademark rights have been "propertized" in recent years, ${ }^{228}$ but remain limited rights that do not equate to traditional property rights. ${ }^{229}$ Rights to use geographic brand names on wine labels are even less significant property rights. ${ }^{230}$ The rights associated with both trademarks and approved wine brand names are entirely use-based rights that continue only so long as the use continues. ${ }^{231}$ However limited, these pre-existing usage rights are a form of property right and thus are potentially vulnerable to a regulatory taking. ${ }^{232}$

In the zoning context, the Supreme Court generally has refused to find a taking because zoning regulations typically do not eliminate all reasonable economically viable uses of a property. ${ }^{233}$ Regulatory takings claims have sometimes been successful where the use of the nonconforming property was required to be terminated immediately. ${ }^{234}$ However, a phaseout of a nonconforming use over a reasonable amortization period does not run afoul of any constitutional prohibition on takings without just compensation. ${ }^{235}$ The typical test to determine reasonableness invokes a

Council, 505 U.S. 1003, 1019 (1992) (explaining that "when the owner of real property has been called upon to sacrifice all economically beneficial uses in the name of the common good, that is, to leave his property economically idle, he has suffered a taking").

228. Trade dress and antidilution protection are key elements of this trend to expand trademark law.

229. These limitations are evidenced by trademark law's prohibition on assignments in gross. Trademarks may not be assigned without any underlying assets or "goodwill." See Lanham Act $§ 10$, 15 U.S.C. $\$ 1060$ (1994).

230. A brand name may be used on a wine label only if ATF has approved its label. See 27 U.S.C. $\S 205$ (e) (Supp. V 2000). See also Moulton \& Spawton, supra note 21, at 9 ("[A regional designation] gives [producers] property rights to their region in a similar way that trade mark law gives property rights to brand owners."). However, ATF regnlations expressly limit the rights conferred to those with approved wine labels; a Certificate of Label Approval may be revoked if there is a change in the relevant laws or regulations. 27 C.F.R. $\$ 13.51$ (2000).

231. But see 15 U.S.C. $\$ 1051$ (b) (1994) (allowing registration and protection of a trademark based on intention to use that mark in commerce within the next three years).

232. Because the rights at stake here are use-based rights, the right at issue cannot be a right to expand a nonconforming use, because that right does not exist at the time of enactment of the law that makes such uses "nonconforming." See, e.g., Melwood Corp. v. Zoning Bd. of Adjust., 528 A.2d 668 (Pa. Commw. Ct. 1987) (holding that because there was no existing nonconforming use, the owner had no constitutional right to natural expansion of that use).

233. See, e.g., Agins v. Tiburon, 447 U.S. 255 (1980); Keystone Bituminous Coal Ass'n v. DeBenedictis, 480 U.S. 470 (1987).

234. See, e.g., Harris v. Baltimore, 371 A.2d 706 (Md. Ct. App. 1977); Standard Oil Co. v. Bowling Green, 50 S.W.2d 960 (Ky. 1932); Jones v. Los Angeles, 211 Cal. 304 (1930).

235. See, e.g., Standard Oil Co. v. Tallahassee, 183 F.2d 410 (5th Cir. 1950), cert. denied, 340 U.S. 892 (1950) (approving ten-year amortization of gas station); National Advertising Co. v. County of Monterey, 211 Cal. App. 2d 375 (1962) (approving five-year amortization requiring removal of sign). 
balancing of public good against private loss. ${ }^{236}$ Such phaseouts are regularly upheld in the zoining of the right to use real property, ${ }^{237}$ which is a right more tangible than any property rights conferred by a trademark or brand name.

The ten-and twenty-year amortization periods proposed here should provide a reasonable period of time for producers to bring their wines into conformity with the grape source requirements and to develop new marketing strategies if necessary. A successful regulatory takings claim here would require a showing that the regulation rendered the property worthless. The phaseout proposed here does not render any marks or brand names worthless or unusable. On the contrary, it allows continued use of the marks on the same type of product, provided they comply with the grape source requirements for the region indicated in their brand name. Therefore, it renders the marks meaningful to the consumer and, by strengthening the integrity of the appellation of origin labeling scheme and thus the value of regional names, provides potentially greater added value to those brand names when used with wines derived from the region indicated by the brand name. Thus, a regulatory takings claim would not prevent implementation of this proposed labeling reform.

\section{Commercial Free Speech}

The Supreme Court has held that commercial speech is protected by the First Amendment, ${ }^{238}$ but that the Constitution accords a lesser protection to commercial speech than to other constitutionally protected expression. ${ }^{239}$ The Supreme Court consistently has struck down regulatory restrictions that are designed to deprive consumers of accurate information about products or services legally offered for sale. ${ }^{240}$ In Rubin v. Coors Brewing Co., the Supreme Court held that alcoholic beverage label information regulated under the FAA Act constitutes commercial speech in the

236. See, e.g., Los Angeles v. Gage, 127 Cal. App. 2d 442, 460 (1954) ("The distinction between an ordinance restricting future uses and one requiring the termination of present uses within a reasonable period of time is merely one of degree, and constitutionality depends on the relative importance to be given to the public gain and to the private loss.").

237. See id.

238. The Court first reeognized this protection in 1975. See Bigelow v. Virginia, 421 U.S. 809 (1975) (holding that advertisements for abortion services in newspapers are protected by the First Amendment); see also Virginia State Bd. of Pharmacy v. Virginia Citizens Consumer Council, Inc., 425 U.S. 748, 762 (1976) (intemal quotations omitted) (citation omitted) (holding that speech that "does no more than propose a commercial transaction" is protected by the First Amendment).

239. Central Hudson Gas \& Elec. Corp. v. Public Service Comm'n of New York, 447 U.S. 557, $562-63$ (1980).

240. See, e.g., Greater New Orleans Broadcasting Ass'n, Inc. v. U.S., 527 U.S. 173 (1999) (invalidating Federal Communications Commission's prohibition on broadcasting lottery mformation under 18 U.S.C. \$ 1304 for violating broadcasters' First Amendment right to advertise lawful private casino gambling). 
sense that label information affects consumers' purchase decisions. ${ }^{241}$ In other recent commercial speech cases, the Court required government regulation of commercial speech to advance the government's interest in a "direct and material way"242 and to be "no more extensive than necessary."243 However, the Court has also made clear that to come under First Amendment protection, commercial speech must not be misleading. Thus, the government may regulate content of commercial speech to prevent the dissemination of information that is false, deceptive, or misleading. ${ }^{244}$ In addition, the Court has held that even true advertisements that inherently risk becommg deceptive do not receive First Amendment protection. ${ }^{245}$

The commercial speech at issue in Rubin v. Coors Brewing Co. was the statement of alcoholic content on alcoholic beverage labels. ${ }^{246}$ An ATF regulation prohibited beer labels from stating alcoholic content in order to promote the government interest in preventing "strength wars" between beer producers. ${ }^{247}$ The Court struck down this regulation because it prevented the display of truthful information on the label and because the government had several less restrictive alternative means of preventing strength wars. ${ }^{248}$

Similarly, the proposed reforms to appellation of origin labeling regulations would regulate true label information (true brand names). However, these proposed reforms would not prevent the display of truthful label information; rather, they would promote the display of truthful label information. Unlike Rubin, where the government's goal was to decrease alcohol consumption, in implementing this reform proposal, ATF would not be attempting to further goals unrelated to the core purposes of its labeling scheme. The purpose of these reforms is to promote truthful commercial speech on wine labels by minimizing deceptive labeling practices. A claim that these proposed reforms would violate a producer's commercial free speech rights would fail because potentially misleading commercial speech is not protected by the First Amendment. ${ }^{249}$

241. 514 U.S. 476 (1995).

242. See id. at 487 (internal quotations omitted) (quoting Edenfield v. Fane, 507 U.S. 761, 767 (1993)).

243. 44 Liquormart, Inc. v. Rhode Island, 517 U.S. 484, 507 (1996) (Stephens, J., plurality).

244. See, e.g., Central Hudson, 447 U.S. at 566.

245. See Friedman v. Rogers, 440 U.S. 1, 13 (1979) (upholding state law prohibiting optometrists from practicing under trade names because of the "significant possibility that trade names will be used to mislead the public").

246. 514 U.S. 476 (1995).

247. Id. at 485 .

248. See id. at $490-91$.

249. See Friedman, 440 U.S. at 13. 


\section{Political Viability of a Comprehensive Reform Proposal}

The reform package outlined above is comprehensive and strict. It no doubt would be very controversial and would meet with much opposition from those holding rights to geographic trademarks or brand names. It might detrimentally affect a handful of producers whose brand names predate identically named AVAs, whose brand names may in fact be more well-known than the identically named AVAs, and who do not intend to mislead any consumers with their labeling practices. ${ }^{250}$ It would no doubt raise the ire of those producers who intentionally trade on the goodwill and renown of the better known AVAs, as well as those producers who market large amounts of wine under semi-generic wine types. This group would include a handful of America's largest wine producers. ${ }^{251}$

However, the proposal would not be without support. Certam aspects of this proposal have been tossed about and proposed by various industry groups and producers. Many premium wime producers who benefit from the renown of their wine regions would likely support the proposal. Industry commentators and consumers also would likely support the proposal. One winemaker stated the industry's present need for meaningful reform as follows:

It is ... time for us to do a little housecleaning with more than stopgap proposals. An economic slowdown with the recent huge grape plantings throughout [California] could see lots of grapes looking for a way to be sold. Napa is not alone. No appellation with a recognizable name will be immune .... We need reasonable "sunset" programs that end this deception and insure that no one can repeat these misleading promotions. ${ }^{252}$

Because of the industry's structure and diverse economic interests, there is unlikely to ever be a true consensus on this issue within the mdustry. To enact any reforms thus would require an ATF that is more proactive than it historically has demonstrated. ATF could, and should, enact a comprehensive set of labeling reforms that serve the core purposes of its grant of labeling authority without caving to the pressures of economically powerful producers whose interests do not serve those core purposes. This commentator's hope is that the well-publicized Bronco case in California will finally provide the stimulus that sets in motion comprehensive, meaningful labeling reform.

250. The prime example of such a brand is Stag's Leap Wine Cellars, which long predates the Stags Leap District AVA and is responsible for much of the notoriety of the region.

251. Those producers who oppose the very notion of appellations could easily avoid difficulties with these regulations by choosing nongeographic brand names and product identifiers while labeling their wines with the country of origin as appellation of origin.

252. Andy Beckstoffer, Letters: Cheers to Laube, WInE Spectator, Aug. 31, 1999, at 38. 


\section{CONCLUSION}

Geographic references are important to the wine business. They are regulated both to prevent consumer deception and to protect the regional producers. The existence of nonconforming uses of geographic terms on wine labels prevents the American wine-labeling regulatory scheme from adequately serving either of these interests. To ensure consistency in wine labeling and to minimize consumer confusion and dilution of regional place names, regulatory reform is needed at the federal level. The solution proposed by this Comment to eliminate nonconformity in the use of geographic terms on wine labels would provide the comprehensive reform that is needed to protect the interests of both wine consumers and producers. This solution would withstand constitutional challenges and would prove more effective than potential alternative solutions. Only after such comprehensive reform has been implemented will the consumer be able to state with certainty that he did indeed "get what he thought he was getting." 253

253. H.R. ReP. No. 74-1542, supra note 40, at 10. 


\section{Appendix A}

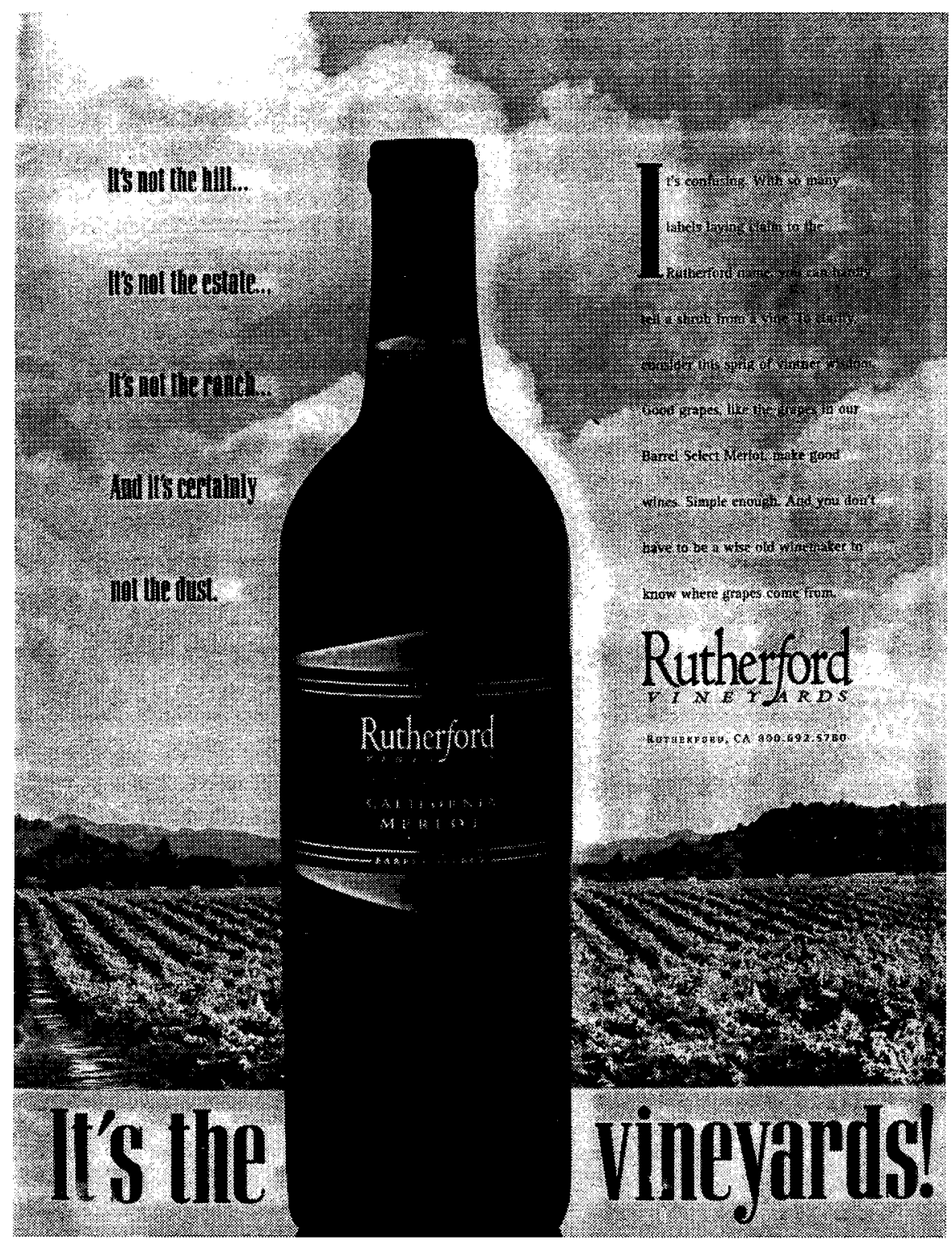


